

\section{Solar Resource Assessment}

D. Renné, R. George, S. Wilcox, T. Stoffel, D. Myers, and D. Heimiller

Prepared under Task No. PVB7.6401

National Renewable Energy Laboratory

1617 Cole Boulevard, Golden, Colorado 80401-3393

303-275-3000 • www.nrel.gov

Operated for the U.S. Department of Energy

Office of Energy Efficiency and Renewable Energy

by Midwest Research Institute • Battelle

Contract No. DE-AC36-99-G010337 


\section{NOTICE}

This report was prepared as an account of work sponsored by an agency of the United States government. Neither the United States government nor any agency thereof, nor any of their employees, makes any warranty, express or implied, or assumes any legal liability or responsibility for the accuracy, completeness, or usefulness of any information, apparatus, product, or process disclosed, or represents that its use would not infringe privately owned rights. Reference herein to any specific commercial product, process, or service by trade name, trademark, manufacturer, or otherwise does not necessarily constitute or imply its endorsement, recommendation, or favoring by the United States government or any agency thereof. The views and opinions of authors expressed herein do not necessarily state or reflect those of the United States government or any agency thereof.

Available electronically at http://www.osti.gov/bridge

Available for a processing fee to U.S. Department of Energy and its contractors, in paper, from:

U.S. Department of Energy

Office of Scientific and Technical Information

P.O. Box 62

Oak Ridge, TN 37831-0062

phone: 865.576 .8401

fax: 865.576 .5728

email: mailto:reports@adonis.osti.gov

Available for sale to the public, in paper, from:

U.S. Department of Commerce

National Technical Information Service

5285 Port Royal Road

Springfield, VA 22161

phone: 800.553.6847

fax: 703.605.6900

email: orders@ntis.fedworld.gov

online ordering: http://www.ntis.gov/ordering.htm 


\section{Preface}

Now is the time to plan for the integration of significant quantities of distributed renewable energy into the electricity grid. Concerns about climate change, the adoption of state-level renewable portfolio standards and incentives, and accelerated cost reductions are driving steep growth in U.S. renewable energy technologies. The number of distributed solar photovoltaic (PV) installations, in particular, is growing rapidly. As distributed PV and other renewable energy technologies mature, they can provide a significant share of our nation's electricity demand. However, as their market share grows, concerns about potential impacts on the stability and operation of the electricity grid may create barriers to their future expansion.

To facilitate more extensive adoption of renewable distributed electric generation, the U.S. Department of Energy launched the Renewable Systems Interconnection (RSI) study during the spring of 2007. This study addresses the technical and analytical challenges that must be addressed to enable high penetration levels of distributed renewable energy technologies. Because integration-related issues at the distribution system are likely to emerge first for PV technology, the RSI study focuses on this area. A key goal of the RSI study is to identify the research and development needed to build the foundation for a high-penetration renewable energy future while enhancing the operation of the electricity grid.

The RSI study consists of 15 reports that address a variety of issues related to distributed systems technology development; advanced distribution systems integration; system-level tests and demonstrations; technical and market analysis; resource assessment; and codes, standards, and regulatory implementation. The RSI reports are:

- Renewable Systems Interconnection: Executive Summary

- Distributed Photovoltaic Systems Design and Technology Requirements

- Advanced Grid Planning and Operation

- Utility Models, Analysis, and Simulation Tools

- Cyber Security Analysis

- Power System Planning: Emerging Practices Suitable for Evaluating the Impact of High-Penetration Photovoltaics

- Distribution System Voltage Performance Analysis for High-Penetration Photovoltaics

- Enhanced Reliability of Photovoltaic Systems with Energy Storage and Controls

- Transmission System Performance Analysis for High-Penetration Photovoltaics

- Solar Resource Assessment

- Test and Demonstration Program Definition

- Photovoltaics Value Analysis

- Photovoltaics Business Models 
- Production Cost Modeling for High Levels of Photovoltaic Penetration

- Rooftop Photovoltaics Market Penetration Scenarios.

Addressing grid-integration issues is a necessary prerequisite for the long-term viability of the distributed renewable energy industry, in general, and the distributed PV industry, in particular. The RSI study is one step on this path. The Department of Energy is also working with stakeholders to develop a research and development plan aimed at making this vision a reality. 


\section{Executive Summary}

Study Area \#4 focuses on the current availability of solar radiation resource data to support distributed grid-tied PV analyses, and the types of data and products needed to support future analysis and operations of significant grid-tied PV penetration. The study also is the impetus for a 5-year research and development plan to assure delivery of these products to end users. Much of the information derived in this study was obtained through interaction with other study-area authors, and with analysts, utility representatives, and solar resource data providers.

\section{Current Knowledge}

There currently are only a few dozen quality solar measurement stations operating in the United States, and only a subset of these stations has been operating for a period long enough to provide accurate information on the interannual variability and long-term trend of the solar resource. Thus, accurately depicting the spatial extent and time-dependent characteristics of the solar resource in the United States required alternative methods. To accomplish this the National Solar Radiation Data Base (NSRDB) was developed. This tool made use of the meteorological and cloud cover observations at National Weather Service Stations around the country as inputs to models to simulate the solar resource at those sites. The NSRDB originally was published in the early 1990s, and provides estimates of the solar resource at 239 stations for the period 1961-1990. Although all available high-quality solar measurement data were included in the NSRDB, nearly all $(>92 \%)$ of the station data were modeled.

The NSRDB recently was updated (2006-2007) to cover the period from 1991 to 2005. The update includes a number of enhancements: inclusion of a far greater number of ground stations (a total of 1454 stations that contain hourly solar and meteorological data), and a 10-km gridded satellite-derived database, developed by the Atmospheric Sciences Research Center at the State University of New York-Albany (SUNY), covering the period from 1998 to 2005 . This enhancement enables hourly solar data for any grid cell location to be combined with hourly meteorological data from one of the nearby ground stations for use in PV simulations.

\section{Results of RSI Solar Resource Assessment Analyses}

Products from the updated NSRDB have been provided to other members of the RSI Study Team to support their analytical work. For example, NREL analysts have received outputs from the photovoltaic performance model PVWatts, derived from NSRDB data for the period 2001-2005 for a number of sites; and Navigant received data for specific collector types and configurations for the year 2003. We have provided GE with 15minute measured data from NREL's Solar Radiation Research Laboratory (SRRL), as well as PVWatts calculations, so that GE can compare these outputs with its model. We also have developed a tool that converts NSRDB data to a format identical with TMY2 data, which very commonly is used in PV performance and buildings load analyses.

Because 2003 was chosen as a key study year, we conducted a number of studies to relate the representativeness of that year to longer-term 1998-2005 records available from SUNY, as well as to the original 1961-1990 NSRDB. Some portions of the country, 
particularly east of the Rocky Mountains, showed resources during 1998-2005 to be lower than during 1961-1990 (in a few cases, nearly 10\% lower), while a few locations in the west showed resources during 1998-2005 to be higher than in 1961-1990 (in some cases, nearly $10 \%$ higher).

Analyses also were performed for each of the four seasons. More portions of the United States showed greater seasonal differences between 1998 and 2005, and 2003, than in the annual comparisons, especially in the spring. Furthermore, much of the country where the differences were noticeable showed that, in general, 2003 had lower resources, again particularly during the spring.

\section{Future Needs and a Multiyear Plan}

A number of critical solar resource data and information gaps have been identified and need to be filled to support expanded grid-tied PV penetration analysis and systems operations in the future. These information gaps include:

- The availability of reliable, sub-hourly data sets (perhaps even sub-minute), either from measurement systems or from model outputs representing the time response of solar PV, especially over compact service territories that could be used as part of load control and load-following studies under high-penetration scenarios with no storage available. Presently only a few measurement stations in the United States provide these data and all of the NSRDB data are hourly values;

- Improved spatial resolution of data sets so that the resource information can be more accurately pinpointed to specific locations where grid-tied PV systems are likely to be installed;

- Solar resource forecasting capabilities over a variety of time steps, including very short term (1-3 hour) for load dispatching, day ahead for system operations, and seasonal and interannual for long-term system planning and cash-flow analyses; and

- A user-interactive data archive that enables users to create and access specialized data sets on-line to meet specific analytical requirements.

To meet these user requirements, a Multiyear Solar Resource Assessment Research Plan incorporating the specific needs of the RSI community was developed at NREL, in conjunction with the DOE Solar Energy Technology Program. The highest priority activities for this research plan (slated to begin in Fiscal Year 2008 (FY08)) are to:

- Initiate R\&D and implement solar resource forecasting procedures that relate specifically to distributed PV analysis and operations;

- Develop procedures for characterizing the climate of different regions of the country using statistical analysis of high data rate (1 minute) solar radiation measurements, using statistics relevant to PV deployment issues; and

- Acquire sub-hourly time series data sets from research-quality measurement sites around the country, including NREL's Solar Radiation Research Laboratory, to facilitate the study of the characteristics of sub-hourly data. 
Other longer-term activities include the following:

- Provide stakeholder outreach and workshops

- Develop operational solar resource forecasting methodologies

- Develop methodology to parameterize sub-hourly PV fluctuation statistics from hourly solar radiation data

- Perform intensive R\&D to assess the relationships between spatial and temporal variability of PV output, using DOE's Atmospheric Radiation Measurement (ARM) and other networked solar measurements

- Develop updated NSRDB products (e.g., TMY2s, data manuals, data-retrieval procedures) relevant to distributed PV analysis

- Enhance the spatial resolution of the satellite-derived data products

- Integrate new and existing data into decision-support tools such as Geographic Information Systems (GIS) tools and PVWatts

- Build on existing on-line data retrieval capabilities to make user-defined data sets readily accessible

- Collaborate with the analysis and utility-planning communities in the areas of utility load modeling using the same databases of solar radiation and weather data. 


\section{Table of Contents}

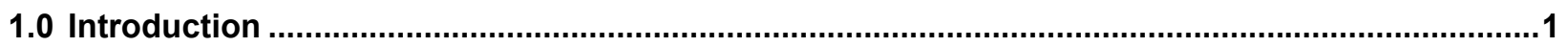

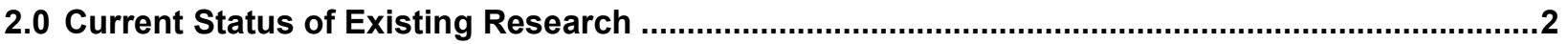

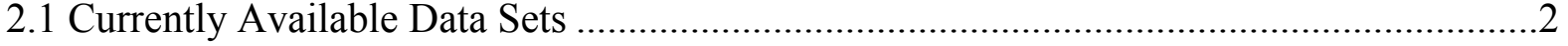

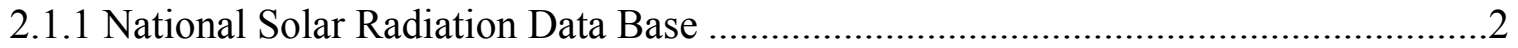

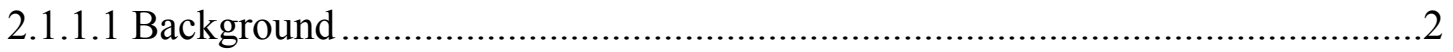

2.1.1.2 NSRDB Statistics Files ............................................................................4

2.1.1.3 Solar Radiation Data Manual for Flat-Plate and Concentrating

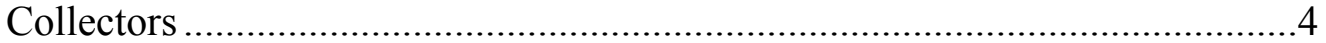

2.1.1.4 Solar Radiation Data Manual for Buildings.....................................................5

2.1.1.5 Typical Meteorological Year ......................................................................

2.1.1.6 Applicability of NSRDB to RSI Applications .............................................6

2.1.2 High-Resolution Satellite-Derived Solar Data (SUNY-Albany) ............................6

2.1.3 High-Quality, High-Resolution Measured Ground Data ......................................8

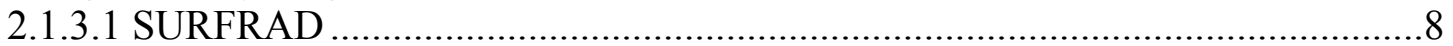

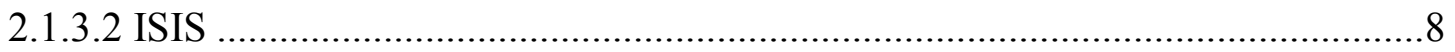

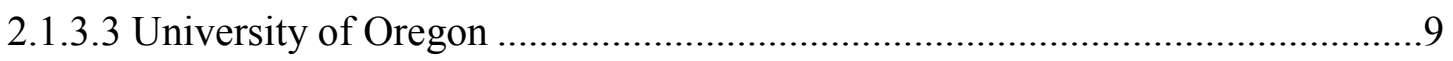

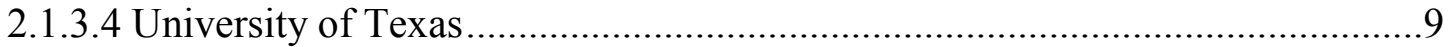

2.1.3.5 NREL Historically Black Colleges and Universities / Cooperative

Network for Renewable Resource Measurements ..........................................9

2.1.3.6 Baseline Surface Radiation Network ............................................................ 10

2.1.3.7 DOE Atmospheric Radiation Measurement Network ....................................10

2.1.4 NASA-SSE Medium Resolution (Worldwide) Data ...........................................10

2.2 Applications of Solar Resource and Weather Data................................................... 12

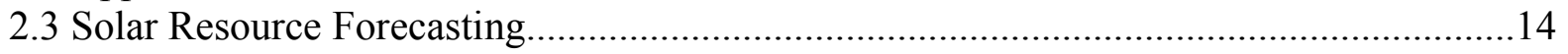

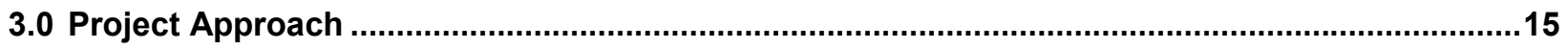

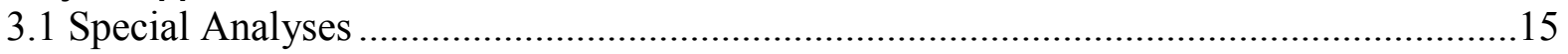

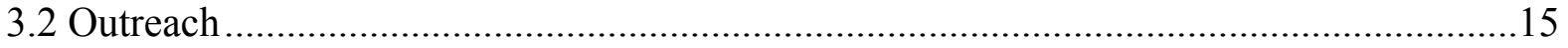

3.3 Multiyear Solar Resource Research Agenda ........................................................15

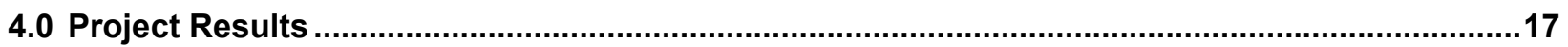

4.1 Special Analyses and RSI Analysis Support ................................................................17

4.1.1 Use of Eight-Year NSRDB Data for Long-Term Mean Values ..............................19

4.1.2 Use of the Year 2003 to Represent the Years 1998-2005 .....................................19

4.1.3 PV Output Fluctuations Using Sub-Hourly Solar Radiation Data...........................22

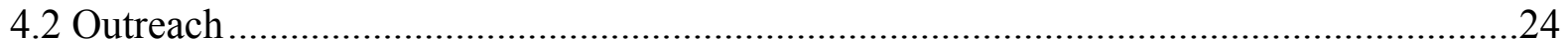

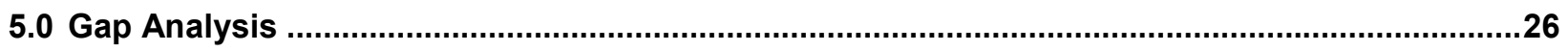

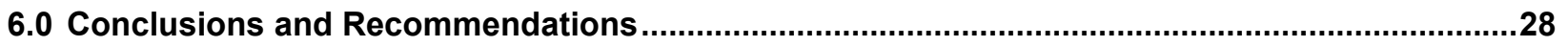

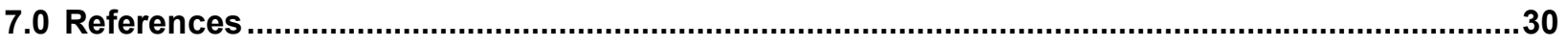




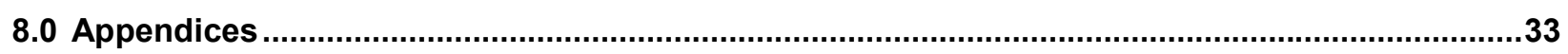

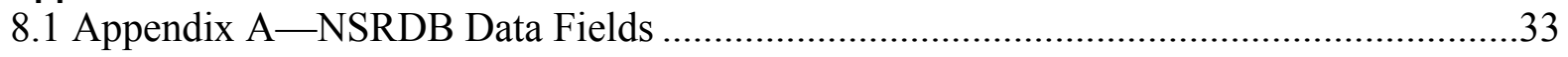

8.2 Appendix B-Sources of Measured Solar Radiation ................................................36

8.3 Appendix C-Questionnaire Used to Solicit Input on Solar Resource

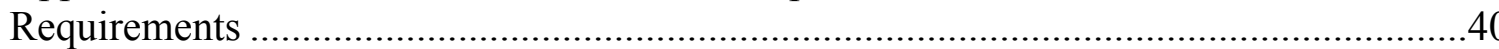




\section{List of Figures}

Figure 2-1. 1991-2005 NSRDB stations over 1961-1990 NSRDB stations. .............................3

Figure 2-2. Gridded latitude tilt data for the United States from SUNY model........................7

Figure 2-3. Sample $1^{\circ}$ grid (dotted lines) resolution of NASA SSE data over the area of Florida. Solid box and dot encompass Miami, FL................................................... 11

Figure 2-4. Data, requirements, model capability, and analysis relationships. .........................13

Figure 4-1. Map background is average of global radiation on latitude tilt, for NSRDB/SUNY data from years 1998-2005. Scale is in $\mathrm{kWh} / \mathrm{m}^{2} /$ day. Points are the difference in annual average between the 1961-1990 NSRDB and the 1998-2005 NSRDB/SUNY data. The locations are the same as the NSRDB/TMY2 sites. Difference expressed in $\mathrm{kWh} / \mathrm{m}^{2} /$ day.

Figure 4-2. The difference in the annual mean value of global irradiance on latitude tilt (nominal PV output), between the year 2003 data and the mean values in years 1998 to 2005. In white areas year 2003 data is within +0.2 $\mathrm{kWh} / \mathrm{m} 2 /$ day of the 8 -year mean. In the pink areas, year 2003 had more resource than the average $(0.2-0.6 \mathrm{kWh} / \mathrm{m} 2 /$ day $)$, and in the blue areas, year 2003 had less resource than average by the same amount.

Figure 4-3. The difference in seasonal mean value of global insolation on latitude tilt (nominal PV output), between the year 2003 and the mean values in years 1998 to 2005 . In white areas, year 2003 is within plus or minus 0.2 $\mathrm{kWh} / \mathrm{m}^{2} /$ day of the 8 -year mean. In pink areas, year 2003 had more resource than the average $\left(0.2-0.6 \mathrm{kWh} / \mathrm{m}^{2} /\right.$ day $)$, while in blue areas, year $2003 \mathrm{had}$ less resource than average, by the same amount. Darker blue and red colors show differences greater than \pm 0.6

Figure 4-4. Frequency of different ramp rates for a PV system, as percent of the total capacity of the PV array. Data from PVWatts for fixed PV system at latitude tilt, using measured solar data from NREL/SRRL, Golden, Colorado, for the year 2003. (Note: vertical scale is truncated, bins centered around $0 \%$ actually extend up to almost 0.5 .)

Figure 4-5. Cumulative frequency of PV ramp rates for year 2003, using 1-minute and 15-minute solar radiation data from NREL/SRRL. Figure 4-5a (top), shows negative PV ramp rates, and Figure 4-4b (bottom), shows positive PV ramp rates.

Figure 4-6. Power spectrum of PV output from Tucson Electric Power 4.59 MW PV plant at Springerville, Arizona. Two years (2004-2005) of data sampled at 1-minute interval (Curtright and Apt 2007)....

Figure B-1. DOE-ARM sites in the Southern Great Plains 


\section{List of Tables}

Table 2-1. SSE Solar Parameter Uncertainty Estimates....................................................... 12

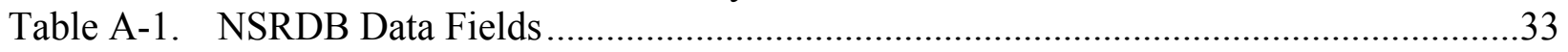

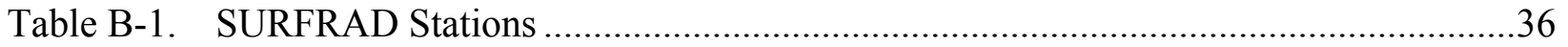

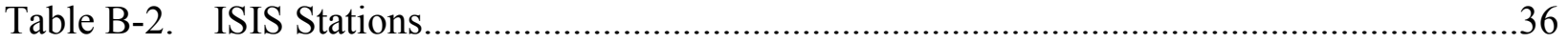

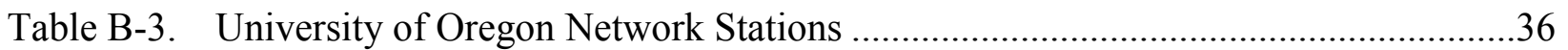

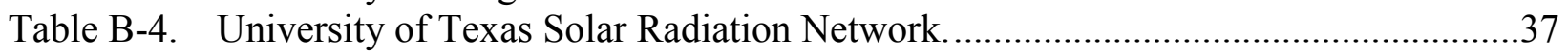

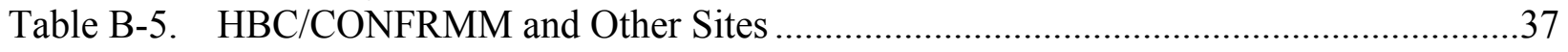

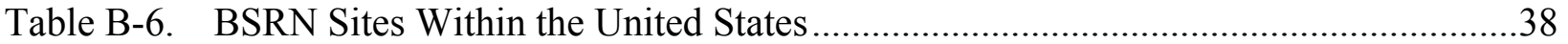




\subsection{Introduction}

Site-specific time series solar resource information, along with associated weather data, always has been essential to the successful design and deployment of solar energy systems. These systems (especially PV and solar water-heating systems, and building integrated systems) generally must be installed close to the load that they are designed to serve, therefore reliable solar data must be available for the point of installation. It is unlikely that any pre-existing measured data will be available for the sizing of these systems or for predicting their performance. Thus, methods for assessing site-time specific data must be developed and applied. The demands for high-quality and reliable site-time specific solar resource information increases as more and more PV systems are tied into the grid in a distributed configuration. The need for future estimates of the resource also increases in order to assist system operators in incorporating distributed PV power in the most cost-effective ways.

Solar resource assessment at NREL historically has been supported through the National Center for Photovoltaics as the Solar Resource Characterization task. The major products arising from this task support the broader solar community, including grid-tied and offgrid PV, solar water-heating systems, Concentrating Solar Power and Buildings. An update to the 1961-1990 National Solar Radiation Data Base (NSRDB), covering the period 1991-2005, was completed in FY 2007. Thus, the timing is ideal for developing a plan to address how solar resource assessment activities should be conducted in the future, particularly with respect to the significant amount of grid penetration of solar technologies anticipated in the United States. A specific need for such a work plan is spelled out in the Renewable System Integration Distributed PV Study Plan.

NREL has substantial expertise and experience in solar resource assessment, and in supporting analysis and deployment activities for many of the major solar technologies, therefore much of the analysis and planning that resulting from this study can proceed rapidly. The emergence of new solar technologies and the new requirements for analysis of grid integrated solar systems, however, require a detailed approach and inclusion of several new stakeholder groups and new solar technologies. 


\subsection{Current Status of Existing Research}

The current status of solar resource assessment in the United States is described with summaries of the availability of modeled data sets, such as NREL's National Solar Radiation Data Base (NSRDB) and NASA's Surface Solar Energy Data Set, as well as the availability of measured data from a number of solar monitoring networks or research programs underway in the United States. The values in these data sets represent one sun (i.e. without benefit of concentration). As with other concentrating technologies, these data are extendable to concentrating PV applications through analysis of the base resource data as it applies to the technology.

\section{$2.1 \quad$ Currently Available Data Sets}

\subsubsection{National Solar Radiation Data Base}

The original 1961-1990 NSRDB held a serially complete hourly resolution data set for all sun-up hours for 239 stations (NREL 1995). In 2007, an updated 1991-2005 NSRDB was released by NREL and collaborators, including the National Aeronautics and Space Administration (NASA), the National Climatic Data Center (NCDC), the Northeast Regional Climate Center, the State University of New York-Albany (SUNY), the University of Oregon, the University of Wisconsin, and the private firm Solar Consulting Services (Wilcox et al. 2007).

\subsubsection{Background}

Changes in the roster of National Weather Service (NWS) sites, as well as the potential for adding NSRDB sites, expanded the updated list of stations from the 239 previously included. Instead, to increase the usefulness of the data set, the update included as many stations and as much data as possible. This update provides data for 1,454 stations (see Figure 2-1). About two-thirds of the stations hold serially complete hourly data for the 15 -year period of record. Nearly all of the solar data contained in the original NSRDB and this update were produced using solar radiation models (NREL 1995). Less than 1\% of the records in this update contain measured data. The NSRDB holds solar and meteorological data, as listed in Appendix A, Table A-1. 


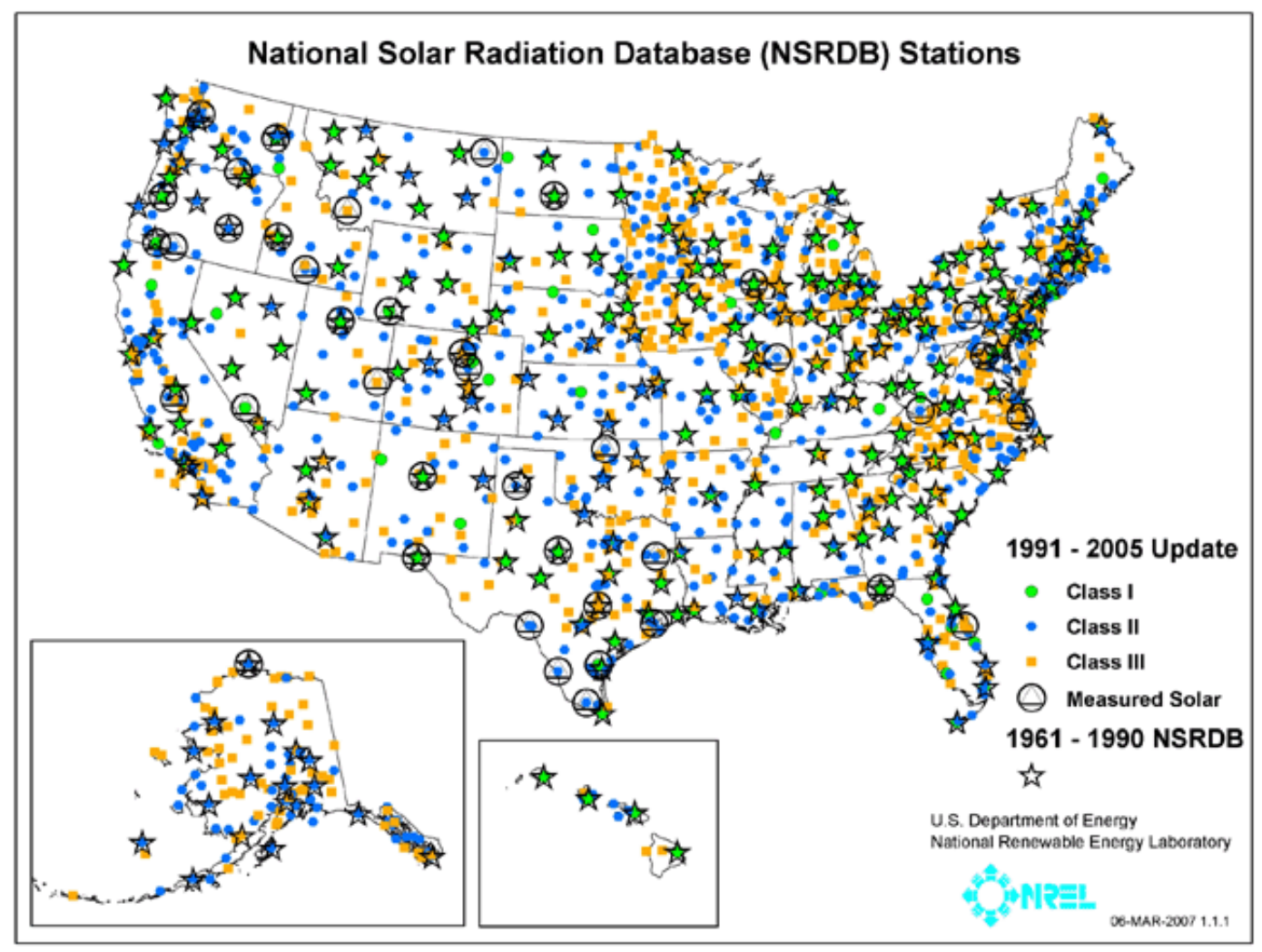

Figure 2-1. 1991-2005 NSRDB stations over 1961-1990 NSRDB stations

The original NSRDB (NREL 1995) was produced using the Meteorological-Statistical (METSTAT) model (Maxwell 1998), which was developed using NWS observations of total and opaque cloud cover and measured solar data from the SOLRAD (Solar Radiation) network (Hicks et al.1996). In the early 1990s, the NWS began supplementing or replacing its conventional manual weather observations with the Automated Surface Observing System (ASOS). For many aviation applications, the ASOS data are comparable with the manual observations. However, for some climatological applications, including solar radiation modeling, the manual and automatic cloud observations are not comparable, as discussed in Perez et al. (2001). Full-sky total and opaque cloud-cover observations made by trained personnel were replaced with cloud estimates from ceilometers, which rely on a temporal evaluation of clouds passing directly above the instrument. The ceilometer has a 12,000-ft reach in altitude and can neither detect high clouds nor distinguish between total and opaque clouds. Additionally, the resolution of the reported sky cover went from tenths or oktas to a coded scheme that, at times, yields only 4 values of sky cover (i.e., clear, scattered, broken, and overcast). This compares with 11 values for units of tenths ( $0-10$ tenths) or 9 for units of oktas $(0-$ 8 oktas).

To compensate for this change, NCDC's ASOS Cloud Data Set (Graumann 2003) - also called the ASOS Supplemental Cloud Product_-was used to derive cloud cover values compatible with the METSTAT model. The Supplemental Cloud Product uses satellite imagery for total cloud-cover estimates that include cloud height information. From this, total and opaque cloud estimates were developed in tenths, with cloud height 
distinguishing between them (Wilcox et al. 2005). (Opaque clouds predominantly occur at lower heights.)

In addition to the NREL METSTAT model, SUNY developed a model that uses Geostationary Operational Environmental Satellite (GOES) imagery to estimate solar radiation. In simple terms, this satellite model uses the inverse relationship between reflected irradiance (that reflected by clouds and atmosphere back to space and the satellite sensor) and ground irradiance (that transmitted through the atmosphere to the Earth's surface). In model-evaluation work conducted as part of the NSRDB project, this satellite model proved comparable with meteorological-based models (Myers et al. 2005). The project also evaluated a model from the Northeast Regional Climate Center that uses ASOS data. It was also found to be comparable with other models; however, the METSTAT meteorological-based model was chosen because of its NSRDB legacy.

Based on simplicity and consistency, the SUNY model would have replaced the METSTAT model but for its limited period of record. The GOES imagery for the project was archived starting in 1998, leaving the period from 1991 to 1997 without coverage. Hence, a hybrid production effort that uses both models was designed.

The NSRDB is available from the National Climatic Data Center (NCDC) or from NREL. See the NSRDB User's Manual at http://www.nrel.gov/docs/fy07osti/41364.pdf for complete information about the data and how to access it.

\subsubsection{NSRDB Statistics Files}

As part of the NSRDB production process summary statistics files are created, providing users with longer-term monthly, annual, or climatic statistics.

- The Daily Statistics Files hold monthly, annual, and period of record means and standard deviations for global, direct, and diffuse radiation; cloud cover; temperature; wind; and heating and cooling degree days.

- The Hourly Statistics Files present monthly and annual mean values in hourly columns for the 3 solar parameters. These files also have data binned by irradiance $\left(50 \mathrm{Wh} / \mathrm{m}^{2}\right.$ bins) to determine the number of hours that the solar irradiance fell within each bin.

- The Daily Persistence Files summarize the length of runs in a month during which the irradiance exceeded or fell below specific energy thresholds (e.g., the number of continuous hours in a month that irradiance exceeded $800 \mathrm{Wh} / \mathrm{m}^{2}$ ). These statistics, for example, are valuable for considering the need for energy storage in a solar conversion application.

All of these files are available on line from NREL and the NCDC.

\subsubsection{Solar Radiation Data Manual for Flat-Plate and Concentrating Collectors}

The NSRDB provides hourly data that often requires conversion to other forms for specific applications. For example, to optimize the amount of energy available for conversion, photovoltaic panels usually are located on a tilted plane or tracking whereas 
the NSRDB holds global horizontal irradiance (in addition to direct beam and diffuse sky irradiance) values. Using various models, NREL produced a data manual of the summary of the 1961-1990 NSRDB data targeted toward PV and solar concentrating applications. The Solar Radiation Data Manual for Flat-Plate and Concentrating Collectors (known as the Red Book) provides monthly climatic means of solar and temperature data for common flat-plate and concentrating technology deployments, and includes mean, maximum, and minimum values. Configurations for solar data include:

- South-facing flat-plate at tilts of $0^{\circ}$ (horizontal), latitude- $15^{\circ}$, latitude, latitude $+15^{\circ}$, and $90^{\circ}$

- One-axis flat-plate tracking at $0^{\circ}$, latitude- $15^{\circ}$, latitude, and latitude $+15^{\circ}$

- Two-axis flat-plate sun tracking collectors

- Direct beam solar for one-axis tracking E-W horizontal concentrating collectors

- Direct beam solar for one-axis tracking N-S horizontal concentrating collectors

- Direct beam solar for one-axis tracking N-S latitude tilt concentrating collectors

- Direct beam, two-axis sun tracking concentrating collectors

The data set also includes climatic meteorological averages for

- Daily maximum and minimum temperatures

- Record maximum and minimum temperatures

- Heating and cooling degree days

- Relative humidity

- Wind speed

NREL plans to update this manual based on the 1991-2005 NSRDB update.

\subsubsection{Solar Radiation Data Manual for Buildings}

To provide data for architects and engineers, the Solar Radiation Data Manual for Buildings (the so-called Blue Book) summarizes data modeled for common window orientations based on the 1961-1990 NSRDB. Targeted toward designing passive lighting for buildings, this manual has limited use for RSI applications. NREL plans also include a possible update for this data manual.

\subsubsection{Typical Meteorological Year}

Typical Meteorological Year (TMY) data sets were produced from the 1961-1990 NSRDB in the TMY2 format (Marion and Urban 1995) for the 239 NSRDB stations. These data sets characterize a long-term data set using cumulative frequency distributions (CFD) for both individual months and multiyear data for each month. For each month of data, the algorithm chooses the single month that most closely matches the CFD for that month's multiyear CFD. A CFD is created for solar and for meteorological parameters, and the CFD for each parameter is given different weighting in choosing a month. 
The 12 selected months are concatenated to produce data representing a 1-year period (the Typical Meteorological Year). Data for several hours across the monthly boundaries are adjusted to avoid discontinuities. The selection process for each typical month also involves removal of candidate months if certain other statistical properties exist, such as anomalous persistence characteristics.

This data set contains data unaltered from the source data set (with the exception of the few hours at the monthly boundaries), providing realistic variability in the resulting time series. The TMY generally does not contain climatic extremes, and this data set is not useful for predicting best-case or worst-case performance. Numerous renewable energy applications have been written to use TMY data.

NREL has plans to produce a TMY for both the 1991-2005 NSRDB and the 10-km gridded data set using gridded meteorological data.

\subsubsection{Applicability of NSRDB to RSI Applications}

As noted above, the NSRDB nearly entirely consists of modeled solar radiation data. Improved spatial resolution, more recent data, and exploitation of current models, make such data useful for prospecting for likely technology deployment locations or for the general sizing of generating capacity. However, caveats such as those listed below also should be considered when using this data set.

- Almost all of the NSRDB solar radiation data for the years 1961-1997 is modeled using the METSTAT model, which modifies cloud cover and aerosol information to enable realistic variability in the data while maintaining climatologically valid means. However, these modifications could introduce errors in the hourly data, making it less useful for performance comparisons for specific historical conditions.

- NSRDB solar radiation data for the years 1998-2005 is modeled using the SUNY GOES satellite model, which does not have the problem noted above. The SUNY data also are available for any location on a 0.1 x 0.1 degree $(10-\mathrm{km})$ grid. SUNY data pose the opposite problem, namely that the aerosol and water vapor data are not randomized, and thus have a less-realistic frequency distribution. This issue has a great effect on Direct Normal Irradiance which is important for concentrating solar power, but has a very small effect on PV performance (George et. al. 2007).

- The NSRDB has hourly data resolution. Some applications (e.g., load matching and variability of generation) require a higher-resolution time scale, such as 15minute or shorter periods.

- The ground-based sites all contain temperature and wind information, which many PV performance applications require. The 10-km gridded data does not have associated meteorological data. However efforts are underway to supply estimated gridded meteorological data set.

\subsubsection{High-Resolution Satellite-Derived Solar Data (SUNY-Albany)}

The 1991-2005 NSRDB update introduced a new product in the form of a 10-km gridded database, which was produced by the State University of New York at Albany (SUNY) 
(Fig. 2-2). One very attractive feature of the SUNY model is its ability to create a highresolution gridded data set (Perez et al. 2002). Whereas the METSTAT model relies on scattered and sometimes sparse point-source ground-based meteorological observations, the SUNY model runs on the virtually seamless (spatial) GOES satellite images (temporal resolution of the GOES data still is approximately hourly). Although GOES images provide up to $1-\mathrm{km}$ resolution, in the SUNY model these data are down-sampled to approximately $10-\mathrm{km}$ resolution $\left(0.1^{\circ} \times 0.1^{\circ}\right)$. This resolution is adequate for most solar radiation resource applications and represents a practical trade-off between resolution and processing and data-storage considerations (the data set holds hourly data for 1998-2005 for more than 100,000 grid cells).

The model uses both GOES-East and GOES-West satellites for the best coverage of the United States. There might be some RSI applications that could benefit from higher resolution data, however, and work is planned to investigate the feasibility of producing — either directly or indirectly — higher-resolution data from the satellite model. Current GOES satellite technology can provide images as frequently as every 15 minutes, but to date no attempts have been made to develop solar estimates from such data.

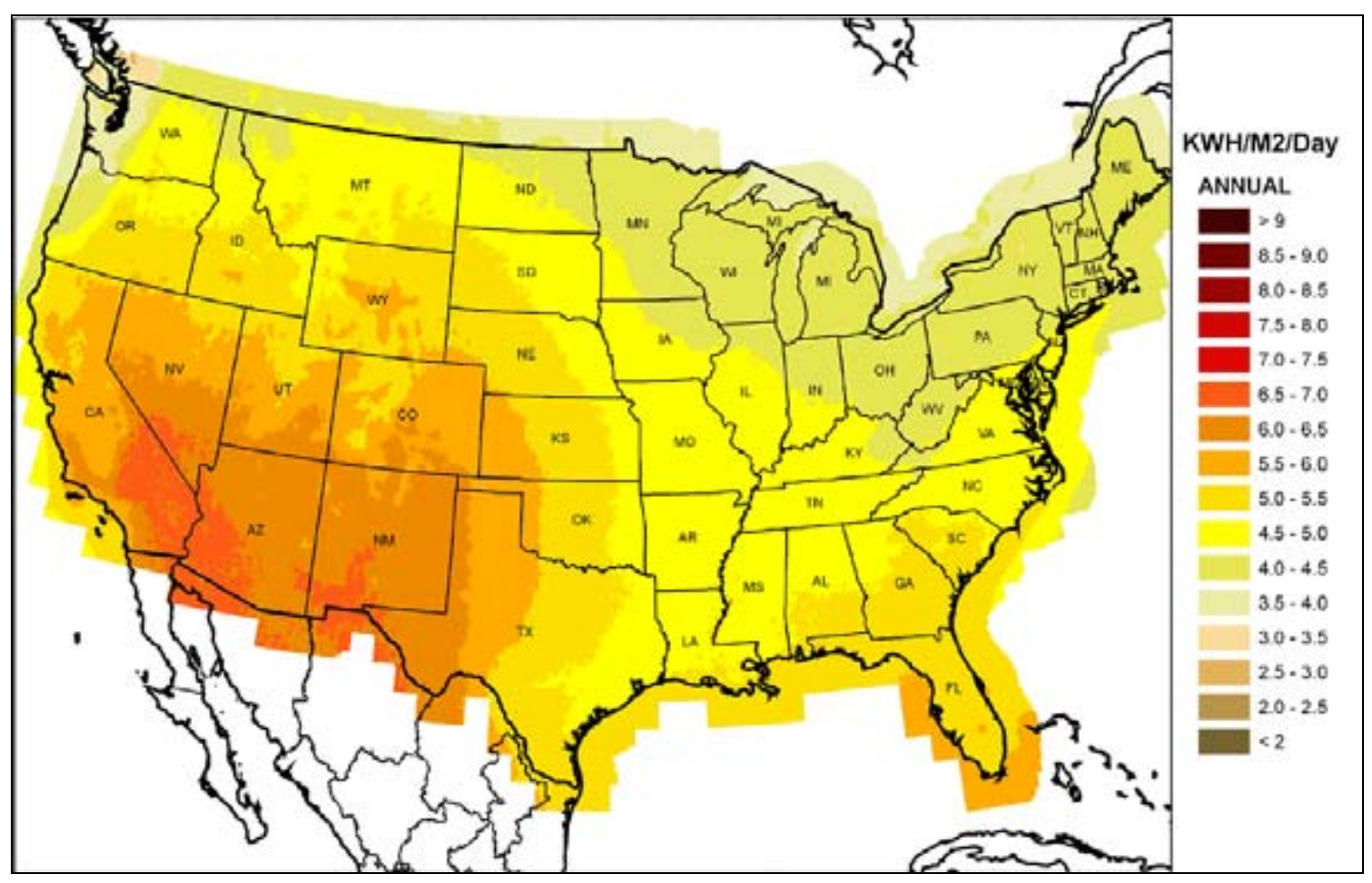

Figure 2-2. Gridded latitude tilt data for the United States from SUNY model

The SUNY model produces estimates of global and direct irradiance at hourly intervals on the $10-\mathrm{km}$ grid for all 50 states. It excludes Alaska above $60^{\circ}$ north latitude and west of $160^{\circ}$ west longitude, where the geostationary satellites cannot resolve cloud cover with necessary detail. The diffuse values in SUNY model were derived from the global and direct irradiance values for each grid cell as the difference between the global and vertical component of the direct irradiance. 
The hourly NSRDB records hold hour-ending irradiance values that represent an integration of the previous hour's irradiance. GOES satellite imagery is a snapshot of the Earth disk and, hence, the irradiance values in the SUNY model grid represent an instant in time rather than an integrated value. Further, the GOES-West satellite images are produced on the hour, and the GOES-East images are produced at 15 minutes past the hour. To make the SUNY model data conform to the NSRDB time convention, its data were shifted in time to better represent the characteristics of hourly integrated values (Wilcox et al. 2007). This approach also allows the gridded data to be used for existing applications that expect a top-of-hour timestamp.

Note that because the SUNY model derives solar radiation measurements from image brightness data and (averaged) ancillary data, it represents a "snapshot" solar radiation value for a particular hour that can be significantly different from METSTAT datawhich is based on estimates from meteorological data and the attendant statistical modifications included in the METSTAT model—particularly under variable atmospheric conditions. Source flags for the solar radiation modeled data indicate the source of the estimated solar radiation data.

The SUNY data are incorporated in the site-based NSRDB data set where practical, but the entire grid is available online as a separate database. The data are organized 1 file per pixel of 8 years of hourly data.

\subsubsection{High-Quality, High Resolution Measured Ground Data}

A summary of solar radiation measurement activities in the United States as of 2000 can be found in Renné et al. (2000). The following sections describe the availability of highquality measured solar resource data.

\subsubsection{SURFRAD}

The Surface Radiation Budget Measurement Network (SURFRAD) was established in 1995 as ground validation for satellite data sets, as well as to provide data for modeling and research into climate, hydrology, and weather (Augustine et al. 2000). These data sets are administered by the National Oceanic and Atmospheric Administration (NOAA) through the Global Monitoring Division in Boulder, CO.

Although the SURFRAD network includes spectral radiation measurements targeted to the validation work, the broadband global, direct, and diffuse solar components and meteorological measurements also are very pertinent to solar renewable energy applications and form a valuable renewable energy database. In addition to the solar parameters, data are available for temperature, relative humidity, wind speed, wind direction, and barometric pressure. Solar data from the SURFRAD stations are recorded as 3-minute integrated values. SURFRAD data are available from http://www.srrb.noaa.gov/surfrad/index.html. The network is comprised of 7 stations in the United States (listed in Appendix B, Table B-1).

\subsubsection{ISIS}

The Integrated Surface Irradiance Study (ISIS) network was commissioned in 1994 to analyze spatial distributions of solar irradiance and time trends at regionally 
representative sites (Hicks et al. 1996). The network is operated by the National Oceanic and Atmospheric Administration through the Global Monitoring Division in Boulder, CO. The network also collects data in the ultraviolet (UV-B) wavebands, but not any meteorological parameters. Like the SURFRAD stations, the high-quality solar radiation data and expert operations have yielded a data set valuable for solar renewable resource assessment. The network lost financial support in 2006, although NOAA continues to collect data from most of the sites. The quality of the recent data is not known.

The ISIS data were recorded in 60- , 15-, and 3-minute intervals, depending on the period. Data are available from http://www.srrb.noaa.gov/isis/index.html. Appendix B, Table B-2, lists the 10 ISIS stations.

\subsubsection{University of Oregon}

The University of Oregon Solar Monitoring Laboratory Network in the Pacific Northwest and western United States includes sites with the longest period of record of high-quality solar measurements in the United States (Univ. Oregon 1999). The network presently has data from 37 sites in Oregon, Idaho, Montana, Utah, and Wyoming with varying instrumentation and periods of record. All sites include air temperature in their measurements, and some include additional meteorological measurements of wind, humidity, or rainfall. Data are recorded in 5- , 15-, and 60-minute intervals depending on the location and period. Data are available at http://solardat.uoregon.edu/index.html.

The University of Oregon network sites are shown in Appendix B, Table B-3. Several sites are at photovoltaic installations (indicated in the table by the [PV] designation).

\subsubsection{University of Texas}

The University of Texas (UT) Solar Radiation Database has roots starting in 1982 and is housed at the Mechanical Engineering Department at UT Austin. The database was expanded in 1995 in support of solar energy-related projects across Texas and holds data from 15 sites (listed in Appendix B, Table B-4). Funding for ongoing solar measurements was discontinued in 2003 but the archive is still maintained. Data can be accessed at http://www.me.utexas.edu/ solarlab/.

\subsubsection{NREL Historically Black Colleges and Universities/ Cooperative Network for Renewable Resource Measurements}

NREL established the Historically Black Colleges and Universities (HBCU) Solar Radiation Network in 1985 in response to a mandate from President Ronald Reagan to bring science and technology to these institutions (Stoffel 1987). The network later was folded into the NREL Cooperative Network for Renewable Resource Measurements (CONFRRM), which was a cooperative effort among NREL and other agencies to conduct long-term solar radiation and wind measurements within the United States. The 13-station network no longer is funded, but several stations continue to collect data and new locations have been added. Current and historical data are archived at the NREL Measurement and Instrumentation Data Center. Several stations are included in the University of Texas solar radiation network. Data are collected at 1- or 5-minute intervals depending on the site and period and are available at http://www.nrel.gov/midc/. Data archived prior to 1997 are 
available from NREL's Renewable Resource Data Center at http://www.nrel.gov/rredc. Sites with data archived by NREL are listed in Appendix B, Table B-5.

\subsubsection{Baseline Surface Radiation Network}

The Baseline Surface Radiation Network (BSRN) was established under the auspices of the World Meteorological Organization's World Climate Research Programme to investigate the effect of solar irradiance on the Earth's climate processes (Ohmura et al. 1998). The BSRN archives data from several dozen sites worldwide, 9 of which are within the United States. Most of the U.S. sites are coincident with the SURFRAD locations. The BSRN network - which was established for climate investigations - also maintains high-quality solar data that support renewable energy applications, as well as various meteorological observations. The BSRN archives data at 1-minute resolution. Data are available from http://bsrn.ethz.ch/. The BSRN sites within the United States are listed in Appendix B, Table B-6.

\subsubsection{DOE Atmospheric Radiation Measurement Network}

The U.S. Department of Energy's Atmospheric Radiation Measurement Network (ARM) establishes and operates field research sites to study the effects of clouds on global climate change (Ackerman and Stokes 2003; U.S. Department of Energy 1996). Three primary locations - Southern Great Plains, Tropical Western Pacific, and North Slope of Alaskawere identified as representing the range of climate conditions that should be studied. Each site has been heavily instrumented to gather massive amounts of climate data. Scientists are using these data to study the effects and interactions of sunlight, radiant energy, and clouds to understand their impact on temperatures, weather, and climate.

The network of Solar Infrared Stations (SIRS) in the Southern Great Plains (parts of Kansas and Oklahoma) provide 1-minute solar irradiance data from 23 locations shown in Appendix B, Figure B-1. The network consists of in situ and remote-sensing instrument clusters arrayed across approximately 143,000 square kilometers (55,000 square miles) and provide data helpful to understanding the mesoscale variability of the solar resources. Solar irradiance data since 1995 are available from the ARM Climate Research Facility Data Archive at http://www.arm.gov/data/.

Direct normal, global horizontal, diffuse horizontal, ground-reflected solar irradiances, and infrared flux data are available at 1-minute resolution (all quality-checked data are at this resolution), but special data sets of 20 -second resolution are archived and available by request. These sub-minute data sets from the ARM network are useful for highresolution temporal and spatial studies. Recognized by the DOE for the technical expertise, NREL is responsible for the radiometer calibrations, data-quality assessment, and operations support of the ARM network of stations.

\subsubsection{NASA-SSE Medium Resolution (Worldwide) Data}

The NASA Surface Meteorology and Solar Energy (SSE) data set is available via the Internet at http://eosweb.larc.nasa.gov/sse/. This description, from the SSE website, is included here because of its popularity with solar designers regarding solar resources. The SSE has the advantage of worldwide coverage, but its disadvantage is limited lower 
spatial resolution than that of other data sets. Resolution in this data set might be improved through research and use in conjunction with the higher-resolution SUNY data set.

The SSE data set is a continuous and consistent 10-year global climatology of irradiance and meteorology data on a $1^{\circ}$ by $1^{\circ}$ grid system. Figure $2-3$ shows the $1^{\circ}$ grid resolution overlaying southern Florida to show the spatial resolution of this data set. For locations where no historical or measured data are available, NASA SSE worldwide data are often the last resort for solar conversion system designers and decision makers who need solar resource data for design and performance modeling applications.

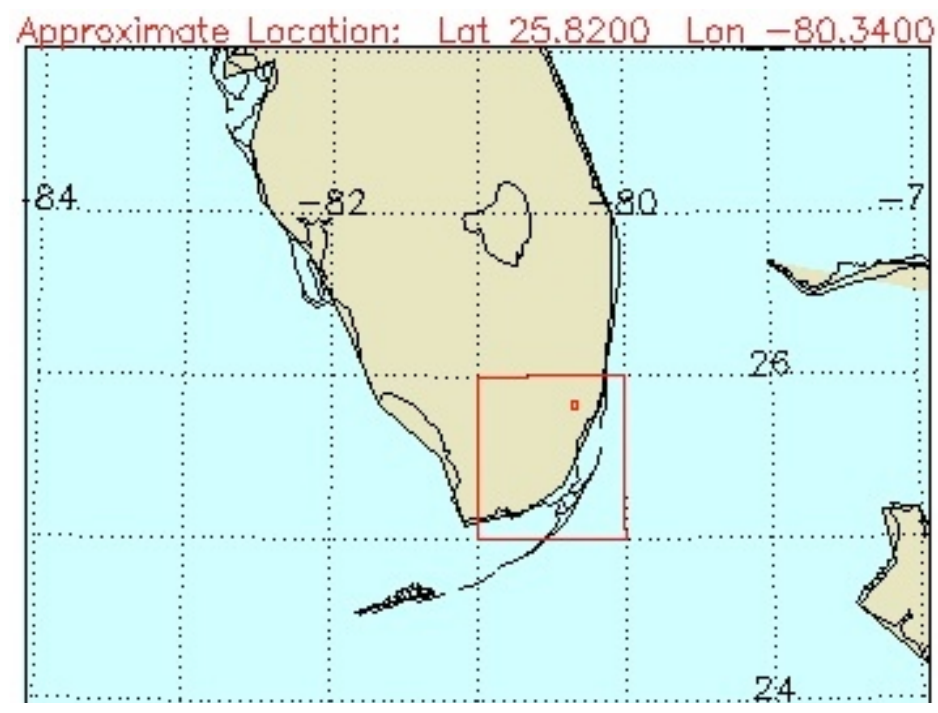

Figure 2-3. Sample $1^{\circ}$ grid (dotted lines) resolution of NASA SSE data over the area of Florida. Solid box and dot encompass Miami, FL.

Although the SSE data within a particular grid cell are not necessarily representative of a particular microclimate or point within the cell, the data are considered to be the average over the entire area of the cell. For this reason, the SSE data set is not intended to replace quality ground measurement data. Its purpose is to fill the gap where ground measurements are missing, and to augment areas where ground measurements do exist. In utilizing the SSE data set, an estimate of the renewable energy resource potential can be determined for any location on the globe. That estimate might be accurate enough for preliminary feasibility studies of new renewable energy projects. Additionally, SSE provides year-to-year variability in terms of 10-year maximums and minimums for a number of parameters. In some situations variability in the data might be more valuable than precise average values.

Estimated root-mean square (RMS) uncertainties of monthly average Release $5 \mathrm{SSE}$ using operational World Radiation Data Center (WRDC) data generally are in the $16 \%$ range, and bias is much less than $1 \%$. The 10-year data period contained $3.5 \mathrm{El}$ Nino years, 2 La Nina years, and 4.5 "near-average" years (Whitlock et al. 2001).

Release 5.1 has been tested against research-quality Baseline Surface Radiation Network data for the 1992 through 1995 period. Table 2-2 shows estimated insolation uncertainties 
with respect to the models used for daily average data. Three-hourly incremental data has the most noise (RMS $=46 \%$, Bias $=-3.2 \%$ ) as would be expected because of satellite navigation uncertainties and cell-size issues. If 3-hourly values are averaged over the month on an hourly basis, the resulting monthly average diurnal values are more accurate $(\mathrm{RMS}=21.7 \%$, Bias $=-3.5 \%)$. Daily values are obtained by averaging 3-hourly values over each day. Daily uncertainties are RMS $=22.6 \%$ and Bias $=-2.5 \%$. Monthly average uncertainties are much more accurate $(\mathrm{RMS}=13.5 \%$, Bias $=-2.5 \%)$.

Table 2-1. SSE Solar Parameter Uncertainty Estimates

\begin{tabular}{lll}
\hline Parameter & Method & RMS (Bias) \\
\cline { 2 - 3 } $\begin{array}{l}\text { Horizontal } \\
\text { Insolation }\end{array}$ & SSE satellite-based Pinker & $13 \%$ to $16 \%(+0.7 \%$ \\
Horizontal Diffuse & to $\%)$ \\
Radiation & SSE/Erbs et al. correlation & $\sim 18 \%(+4 \%)$ \\
Direct Normal & SSE/Extended Page (74 reference sites) & $\sim 20 \%(+3 \%)$ \\
Radiation & SSE/RET Screen-type (hourly angular conversion) & $\sim 15 \%(-9 \%)$ \\
& $\begin{array}{l}\text { SSE/Extended Page (empirical Staylor angular } \\
\text { conversion) }\end{array}$ & $\sim 24 \%(+2 \%)$ \\
\hline
\end{tabular}

SSE also provides diurnal information in terms of monthly averaged 3-hourly insolation. Estimated 3-hourly monthly uncertainty is $21.7 \%$ (RMS) and $-3.5 \%$ (Bias). Tables of daily values can also be obtained. Daily uncertainties are $22.6 \%$ (RMS) and $-2.5 \%$ Bias.

Version 6.0 of the SSE has been reported as near release. Improvements in that version include extension of the period of record to 22 years (July 1983 to June 2005). Fourteen solar radiation and temperature parameters are included in the daily average time series for any portion of the 22-year period of record. The new estimates are based on Goddard Earth Observation System radiation and temperature data assimilation and analysis model version 4 (GEOS-4). Validation and determination of uncertainties in solar, temperature, and wind data was done with National Climatic Data Center and various solar radiation measurement data sets, such as SURFRAD and BSRN.

\subsection{Applications of Solar Resource and Weather Data}

There are several decision tool models available — such as PVWatts and the Solar Advisor Model — which model system performance based on hourly Typical Meteorological Year (TMY2) data. However a comprehensive investigation of model performance with respect to higher time resolution solar irradiance data is needed. Moore and Cameron in their paper, "System Modeling and Performance Database Development" (Moore and Cameron 2007) in the 2007 DOE SETP Program Review illustrate the relationship between input parameters, model capability, and data (input and output), and Solar America Initiative requirements (Fig. 2-4). The authors discussed the evaluation of Solar Advisor Model with respect to 5 other models and a measured PV performance data set. They found differences from $2 \%$ to $17 \%$ from the measured data. 


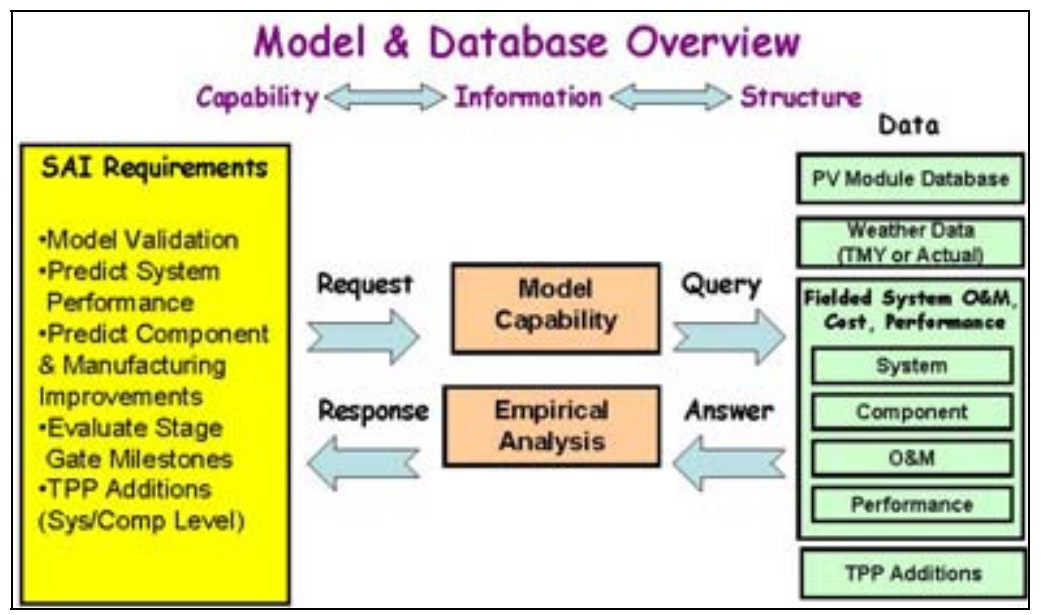

Figure 2-4. Data, requirements, model capability, and analysis relationships

The following quote comes directly from Moore and Cameron (2007).

The model inputs and calculations serve as guidance to examine the parameters required for benchmarking, database development structure and analytical requirements. Readers are reminded that the models use TMY2 data for the weather input. An initiative is underway at the national laboratories to validate models against measured data for a variety of systems. One approach in the effort will be to substitute measured weather data for TMY2 data files. Although some models results were within 5\%, calculated results can be very sensitive to changes in input parameters, especially assumptions often lumped into a derate value.

The purpose of TMY data always has been to provide a means of comparing the performance of several different (crystalline silicon technology) systems on an hourly basis under identical solar and weather conditions. Usually the Sandia PVFORM model (embedded in PVWatts) has been used for these analyses. With the increasing variety of systems, deployment scenarios, and analysis tools, the variability in photovoltaic system performance as a function of time and time resolution are becoming more important. Such investigations require appropriate time resolution data, and means of generating and validating such data.

Sections 4.1.1 and 4.1.2 discuss the variability from year to year of available solar radiation data with respect to a specific or selected reference year. Variations of the magnitude shown there (at times greater than $0.6 \mathrm{kWh} /$ day, based on hourly average data) could be easily exceeded when periods exceeding the 8 years in this preliminary study are examined.

In section 4.1 .3 a preliminary analysis of the changes in photovoltaic system performance (calculated using a modified version of PVFORM in conjunction with PVWatts) shows that moving from hourly to 15 -minute to 1-minute data greatly impacts the ability to resolve photovoltaic system ramping with respect to input data fluctuations. More detailed studies of this nature are needed to resolve issues with such variations distributed 
over space (e.g., large system areas) as well as time. Means of addressing these input data needs and issues should be investigated, as described in section 4.1 below.

\subsection{Solar Resource Forecasting}

Based on discussions with industry representatives and private-sector consultants, it is thought that the need for reliable short-term and day-ahead forecasting will increase as penetrations of grid-tied PV increase. At a recent meeting at the California Independent System Operators (CAISO), for example, day-ahead forecasting for wind energy applications was considered important because knowledge of the availability of the wind resource impacts decisions on implementing power purchase contracts with outside providers to maintain system performance and meet loads. (Specifically, the ISOs need to make system availability forecasts at a 15-minute increment for traditional power generating equipment; for wind system operations, day-ahead wind energy forecasts currently are viewed as the most practical at this stage of wind farm development.) CAISO recognizes that, as PV penetrations increase in the California energy sector in the next few years, the need for day-ahead solar resource forecasts also will increase, and so CAISO is exploring potential options to provide them.

The industry also has expressed the need to better understand the capability of longerterm forecasts (seasonal, annual, interannual) to assist with system planning. In particular, a better understanding of long-term solar resource trends at a site or in a region would be useful for infrastructure planning and cash-flow analyses.

Currently there are no operational solar resource forecasts being implemented in the United States, although several approaches for implementing forecasting procedures have been explored (Perez et al. 2007). In Europe the development of reliable 1- to 3-dayahead forecasts is underway by several institutions, and some operational forecasts are being used in a limited basis. Developing solar resource forecasting methodologies is a major activity under the International Energy Agency Solar Heating and Cooling Programme's Task 36: "Solar Resource Knowledge Management," for which NREL is the Operating Agent see http://re.jrc.cec.ue.int/iea-shc-task36/. This task provides an excellent opportunity for researchers from around the world to share their approaches to and experiences with implementing solar resource forecasts. 


\subsection{Project Approach}

A team composed of solar resource assessment experts at NREL and key outside researchers who have had a long working relationship with NREL was assembled to develop the work plan. From June 2007 to September 2007, the team undertook a variety of activities. Included were technical analyses as well as internal and external outreach with representative experts in distributed power, grid integration, utility planning, and operations, and also including researchers, modelers, and system designers. The team created a work plan that defines the current status of solar resource information, the long term needs of the user community, and a multiyear research agenda to meet these needs. The final deliverable was used to guide solar resource assessment Annual Operating Plans (AOPs) as part of the overall National Center for Photovoltaics (NCPV) planning process.

\subsection{Special Analyses}

As part of RSI, multiple teams of researchers are attacking various problems related to integration of large amounts of PV into the electrical grid. The NREL Solar Resource Team adopted the approach of: supplying the needs of the analytical tasks as best as possible using the latest and most complete data sources possible; and conducting limited independent analyses based on the perception of the needs of the RSI analytical effort, and of the broader utility industry. The results are shown in section 4.1.

\subsection{Outreach}

The expert team developed a variety of outreach activities to secure information on the needs of the Distributed PV community for the accuracy and completeness of solar resource information, the types of products that should be developed from solar resource data, and how the data can best be accessed by users. Outreach activities included targeted meetings with experts at NREL and with external data users. In particular the team took advantage of major venues occurring during the spring and summer of 2007, such as the Solar 2007 Conference in Cleveland in July, where a forum on NREL's new NSRDB was held, to capture critical information on the needs for solar resource information by the development community.

\subsection{Multiyear Solar Resource Research Agenda}

As analyses and information were gathered by the expert team, the results were incorporated into a multiyear research agenda and implementation plan for how resource assessments, measurements, data, and analysis methods can be advanced to support grid integration. The work plan addresses the following elements:

- Identifying solar resource data requirements needed to support grid stability analysis in grid-interconnected systems;

- Conducting R\&D for improving the time and space resolution of data sets, improving their accuracy and reliability, better assessment of atmospheric aerosols, and mitigate the impact of snow cover on satellite-derived methodologies; 
- Assessing the need and feasibility of forecasting solar resource information in the very short term ( 5 minutes to 3 hours) and the midterm (1 to 3 days);

- Determining deficiencies in instrumentation and measurement programs and, if justification exists, to fill gaps or provide support to ongoing "legacy" measurement networks to assure their continued operation for validating and improving solar resource models; efforts will be made to incorporate existing measurements from PV installation, and can include meteorological data;

- Identifying specialized data products and tools required by planners and developers in evaluating and implementing grid-interconnected systems; and

- Determining the most effective means of making solar resource data and products easily accessible to the development community. 


\subsection{Project Results}

\subsection{Special Analyses and RSI Analysis Support}

Early in the RSI project, the NREL Solar Resource Team made users aware of the data available, and supplied the most appropriate datasets to RSI analysts who requested them. The initial recommendations for available, useful datasets were as follows:

- NSRDB data from 1050 stations (1998-2005) with SUNY modeled solar irradiances and observed weather parameters

- PVWatts hourly output - plane of array radiation, DC output, AC output from a standard PV system

- GIS analysis to assign the results to specific regions

- Custom sub-hourly solar and weather data from selected measurement sites

After several months of experience in collaborating with the RSI team, the extended list of recommendations is as follows:

- Use recent data from the new NSRDB and measurement sites, rather than relying on the sparse (239 U.S. sites) TMY2 dataset (based on the 1961-1990 NSRDB). Use of recent data allows for direct load-matching with utilities, and the higher spatial resolution of the new NSRDB allows a closer match between the chosen region for analysis and the data.

- For time-dependent load-matching analysis, NREL and subcontractor analysts selected the year 2003 to perform extensive analysis. NREL has documented the differences in solar radiation and PV output between 2003 data and the 19982005 average. For applications that could be affected by the representativeness of this year, NREL suggests that the analysis community run models on multiple years of hourly NSRDB data.

- For mean values of PV production, analysts should use averages from the time period 1998-2005, for which NSRDB data from 950 stations (1998-2005) with SUNY modeled solar and observed weather are available. In some cases, for specific locations average values based on the 1961-1990 NSRDB might be adequate.

- NREL has agreed to provide hourly or custom sub-hourly output from the PVWatts model to the analysis teams. The inputs to the PVWatts calculator are the best available solar radiation, temperature, and wind-speed data for the requested location. This usually is the SUNY satellite modeled hourly solar radiation, with surface-observed weather data from the NSRDB. The outputs from the PVWatts calculator are hourly (or sub-hourly) incident (tilted surface or tracker) radiation, DC output, and AC output from a standard PV system.

- NREL will provide custom sub-hourly solar and weather datasets from selected measurement sites for PV simulation if sub-hourly analysis is required. Subhourly PVWatts output also can be provided. 
Based on these recommendations, during FY07 the NREL Solar Resource Team has provided input data to the following task areas:

- Production Cost Modeling for High Levels of PV Penetration, Paul Denholm (NREL) - Hourly PVWatts output, Years 2001-2005, for 950 NSRDB locations, for 14 different collectors including 1-axis and 2-axis trackers.

- Production Cost Modeling for High Levels of PV Penetration, Paul Denholm (NREL) - 15-minute PVWatts output from available years (2001 and 2002) for 7 solar measurement sites in Texas.

- PV Market Penetration Scenarios, Jay Paidipati (Navigant)—Hourly TMY2 formatted data from year 2003 for 10 cities, for building load (electrical load) analysis. Building load simulations were performed by NREL buildings engineers and then supplied to Navigant. These applications were very sensitive to temperature, thus requiring representative weather data.

- PV Market Penetration Scenarios, Jay Paidipati (Navigant)-Hourly PVWatts output, Year 2003, for approximately 80 cities, including some in Alaska and Hawaii. Fixed flat-plate collectors only.

- Enhanced Reliability of PV Systems with Energy Storage and Controls, Devon Manz, Jovan Bebic (GE) - 15 minute solar radiation, with weather data, Year 2003, for 3 sites (Hanford, CA; Golden, CO (NREL/SRRL); and Sterling, VA).

- Production Cost Modeling for High Levels of PV Penetration, Paul Denholm (NREL) - Hourly PVWatts output, "grid-centric" PV calculations, for all cells in a region of the Colorado Front Range area, and Southern California area. (Gridcentric; uses center of SUNY 10-km grid cell as station location and pulls in weather data from the nearest appropriate NSRDB station.)

Feedback regarding the usefulness of the data has been very positive.

The Solar Resource Team also produced the following independent analytical results:

- Long-term mean values for PV incident radiation (latitude tilt) were mapped for the years 1998-2005, compared to the original 1961-1990 NSRDB. This will help guide interpretation of mean value results using either of these datasets.

- Mean values for PV incident radiation for the year 2003 for all 10-km grid cells were compared to the average of years 1998-2005. This analysis also is available by season of the year. This will help in interpreting results using the hourly data from the year 2003, relative to the average solar climate.

- Using high resolution (1-minute) solar radiation and weather data from the NREL Solar Radiation Research Laboratory (SRRL), the Team produced an analysis of the rate of change of PV system output for all hours of the year. This will demonstrate the need for higher resolution data for grid stability analysis.

These analyses are detailed in the sections below. 


\subsubsection{Use of Eight-Year NSRDB Data for Long-Term Mean Values}

In Figure 4-1, the circles show the location of stations in the original 30-year NSRDB. The 1998-2005 satellite-derived data are compared to these stations. The blue circles indicate that the satellite-derived data are lower than the old NSRDB, and the red circles designate those sites where the satellite-derived data are higher than the old NSRDB. A white circle means that the difference between the two periods is within $\pm 0.1 \mathrm{kWh} / \mathrm{m}^{2} /$ day. Throughout much of the country, the solar resources for the period 1998-2005 were very similar to the period 1961-1990. Some portions of the country, particularly east of the Rocky Mountains, showed resources during 1998-2005 to be lower than for 1961-1990 (in a few cases nearly 10\% lower), and a few locations in the west showed resources during 1998-2005 to be higher than 1961-1990 (in some cases nearly $10 \%$ higher).

In general, this analysis demonstrates that mean values from 1998-2005 data from the new NSRDB are consistent with the 1961-1990 NSRDB. Analysts using either data set should consult this map and be aware of the potential differences for their region of interest.

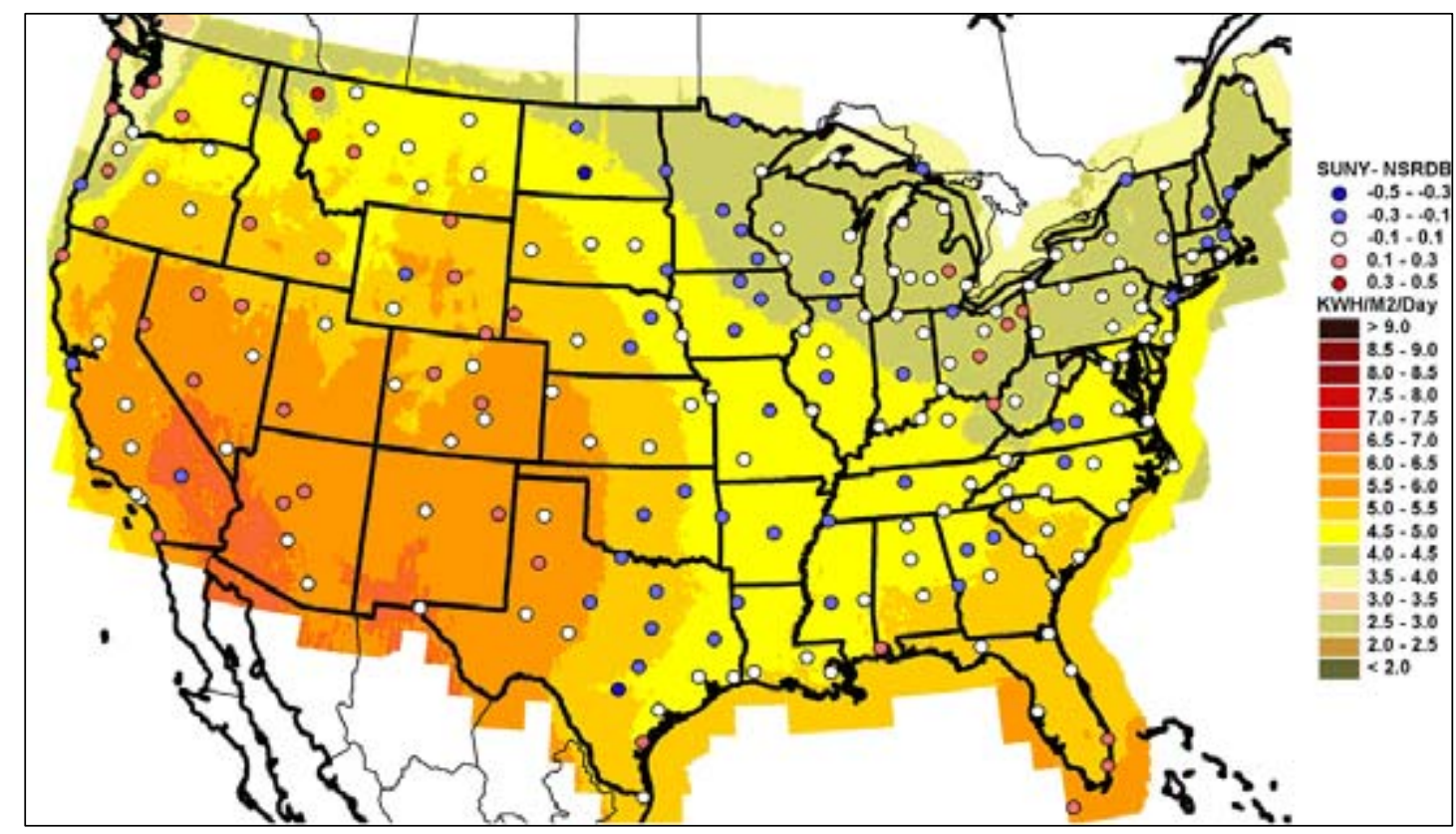

Figure 4-1. Map background is average of global radiation on latitude tilt, for NSRDB/SUNY data from years 1998-2005. Scale is in $\mathrm{kWh} / \mathrm{m}^{2} /$ day. Points are the difference in annual average between the 1961-1990 NSRDB and the 1998-2005 NSRDB/SUNY data. The locations are the same as the NSRDB/TMY2 sites. Difference is expressed in $\mathrm{kWh} / \mathrm{m}^{2} /$ day.

\subsubsection{Use of the Year 2003 to Represent the Years 1998-2005}

The year 2003 was chosen as a key study year by the Team; thus we conducted a number of studies to relate the representativeness of this year to longer-term 1998-2005 records available from SUNY, as well as to the original 1961-1990 NSRDB. Figure 4-2 shows the comparison of the year 2003 with the 1998-2005 period. The pinkish-red areas in the 
Pacific Northwest and northern Midwest indicate that resources were slightly higher in 2003 than for the 1998-2005 period; the blue areas in the eastern United States and south Texas show that the resources were lower in 2003 than during the 1998-2005 period.

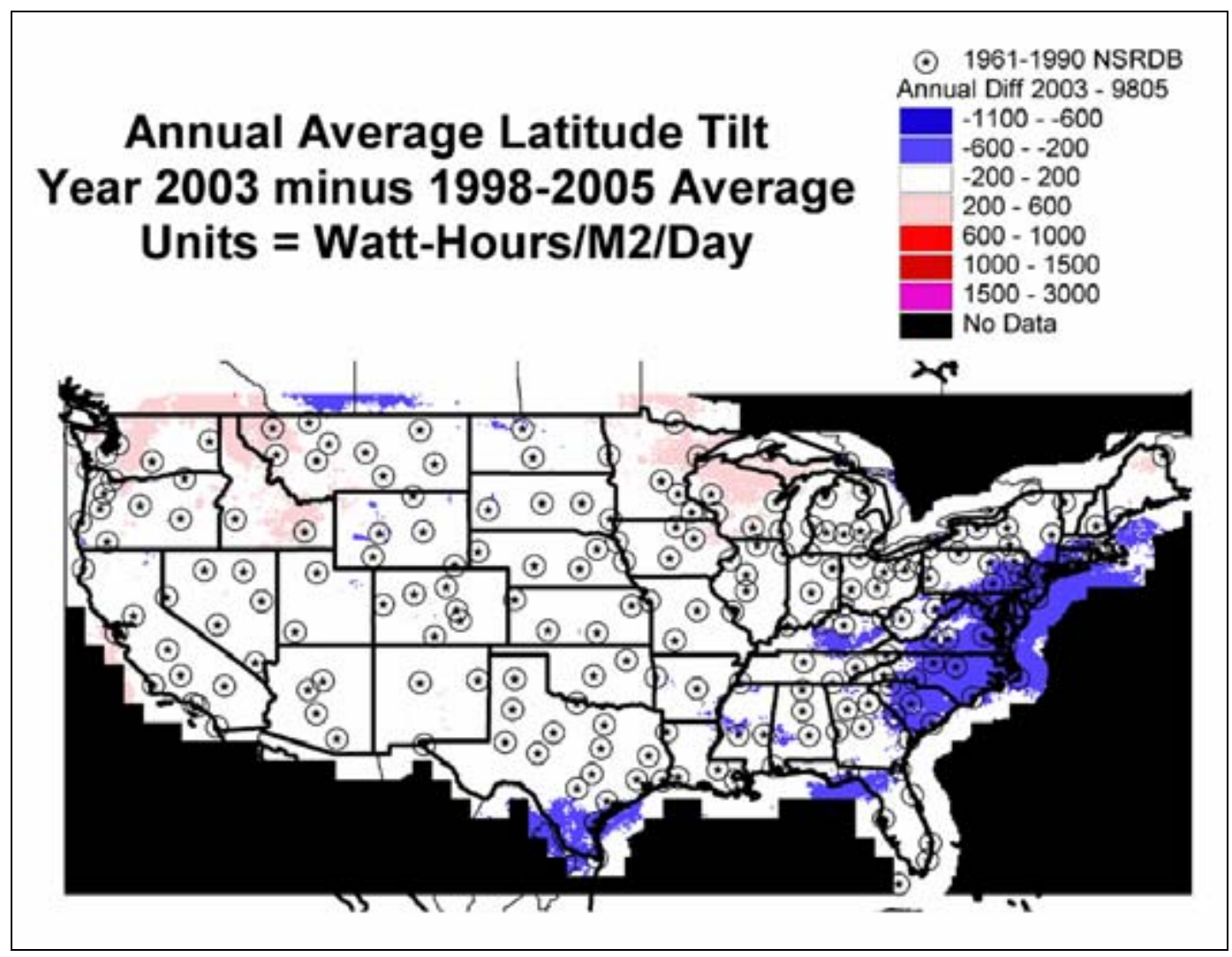

Figure 4-2. The difference in the annual mean value of global irradiance on latitude tilt (nominal PV output), between the year 2003 data and the mean values in years 1998 to 2005. In white areas year 2003 data is within $\pm 0.2 \mathrm{kWh} / \mathrm{m}^{2} /$ day of the 8-year mean. In the pink areas, year 2003 had more resource than the average $\left(0.2-0.6 \mathrm{kWh} / \mathrm{m}^{2} / \mathrm{day}\right)$, and in the blue areas, year 2003 had less resource than average by the same amount.

Analyses similar to Figure 4-2 were also done for each of the four seasons (Fig. 4-3). More portions of the United States showed greater seasonal differences between 19982005 period and 2003 than shown in the annual comparisons, especially in the spring. Furthermore, in much of the country where the differences were noticeable, data showed that in general 2003 had lower resources, again particularly during the spring.

This analysis also demonstrates the importance of being aware of the differences between monthly or annual data sets and the longer-term means. For most RSI applications, the time correlation of the PV output with electrical load is more important than the mean values. However, using 1 year with somewhat anomalous weather could influence the result. For example, if a researcher is interested in fairly infrequent events which occur mostly in the spring, when PV output exceeds load for a high penetration system, year 2003 might be lacking in those cases due to extra cloudiness. The solution is to use more years of data for the analysis. 


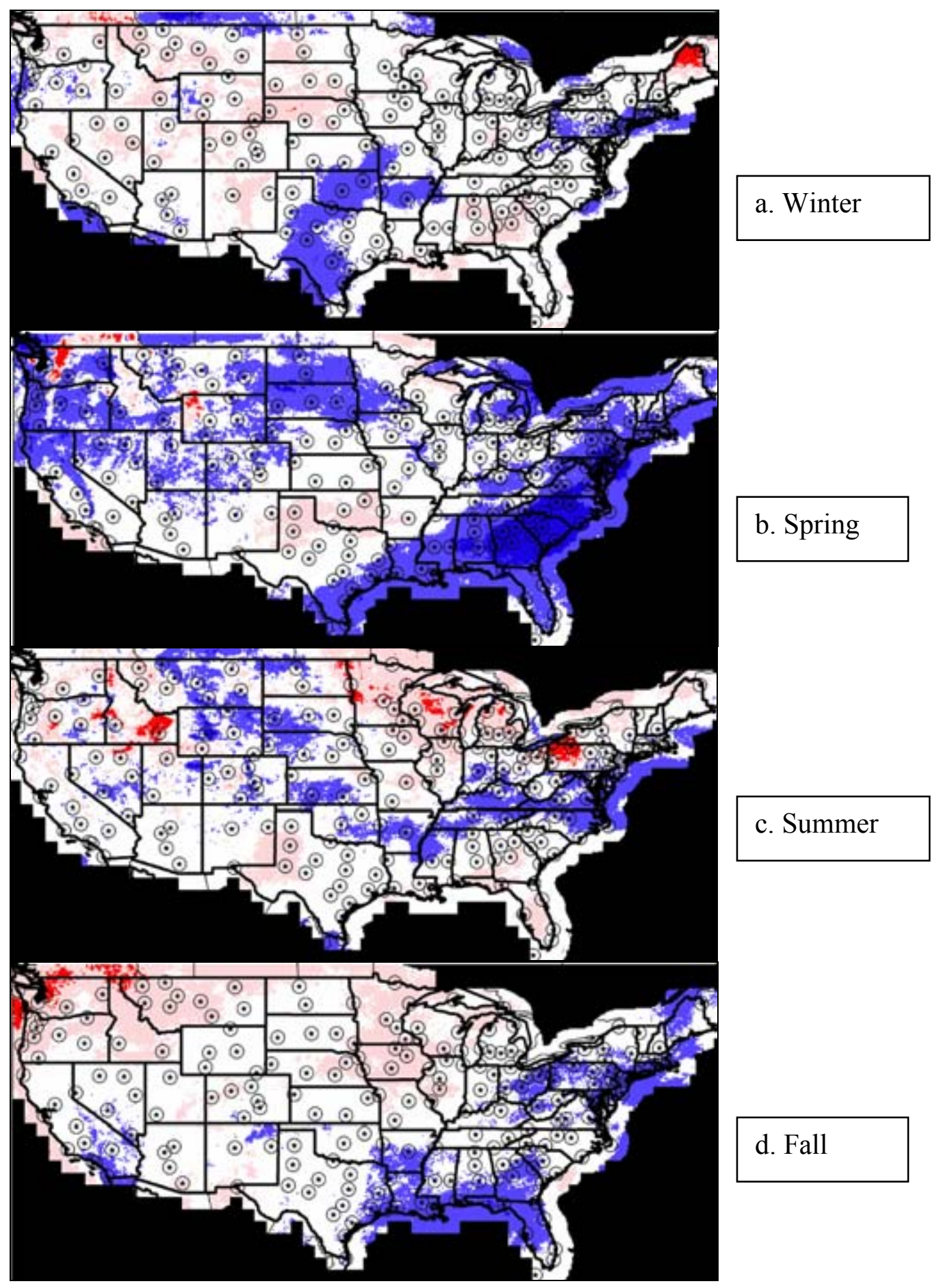

Figure 4-3. The difference in seasonal mean value of global insolation on latitude tilt (nominal PV output), between the year 2003 and the mean values in years 1998 to 2005. In white areas, year 2003 is within $\pm 0.2 \mathrm{kWh} / \mathrm{m}^{2} /$ day of the 8-year mean. In pink areas, year $2003 \mathrm{had}$ more resource than the average $\left(0.2-0.6 \mathrm{kWh} / \mathrm{m}^{2} /\right.$ day $)$, and in blue areas, year 2003 had less resource than average, by the same amount. Darker blue and red colors show differences greater than \pm 0.6 . 


\subsubsection{PV Output Fluctuations Using Sub-Hourly Solar Radiation Data}

To demonstrate the effect of rapid fluctuations in solar radiation on PV systems, 1 year of data from NREL/SRRL in Golden, Colorado, was processed. The original data were recorded at 1-minute intervals, and includes the temperature and wind speed at the same site. The same data also was processed into different mean intervals. We computed the AC output of a PV system, fixed flat-plate at latitude tilt, using a modified version of the PVWatts model. Also computed was the ramp rate up or down in percent of the maximum output of the PV array per minute. With 1-minute data, the number of high ramp rate events, both positive and negative, is much greater than with 15-minute data. The histogram of the results is shown in Figure 4-4.

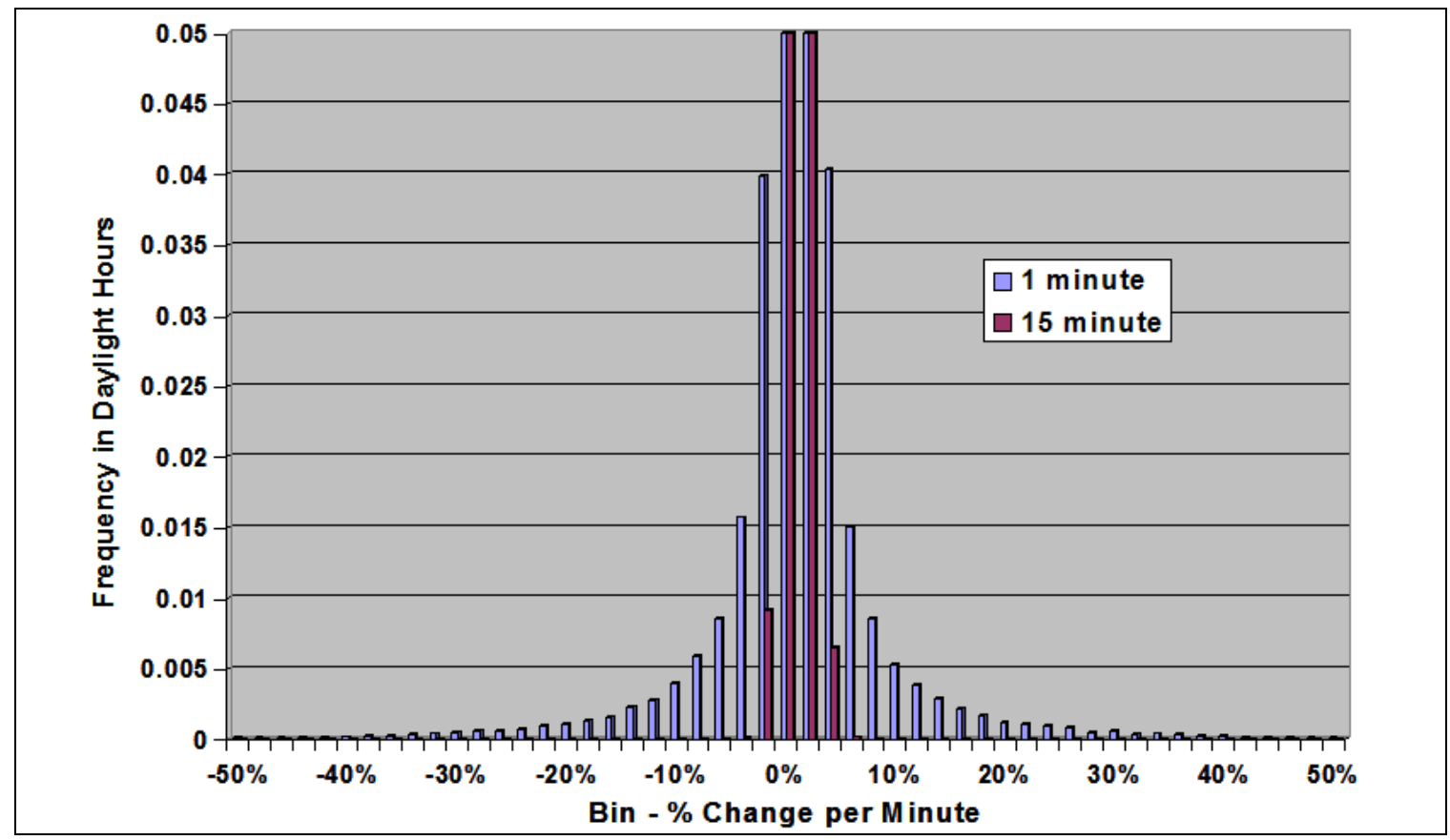

Figure 4-4. Frequency of different ramp rates for a PV system, as percent of the total capacity of the PV array. Data from PVWatts for fixed PV system at latitude tilt, using measured solar data from NREL/SRRL, Golden, Colorado, for the year 2003. (Note: vertical scale is truncated, bins centered around $0 \%$ actually extend up to almost 0.5 .)

Examination of the "tails" of this distribution, expressed as a cumulative function, in Figure 4-5a shows, for example, that there are more than 20 hours per year when the PV output is dropping by more than $20 \%$ of capacity per minute. Figure $4-5 \mathrm{~b}$ also shows that there also are more than 20 hours per year when the PV output is increasing by more than $20 \%$ of capacity per minute. The 15 -minute data are unable to resolve ramp rates of more than about $5 \%$ of PV capacity. 

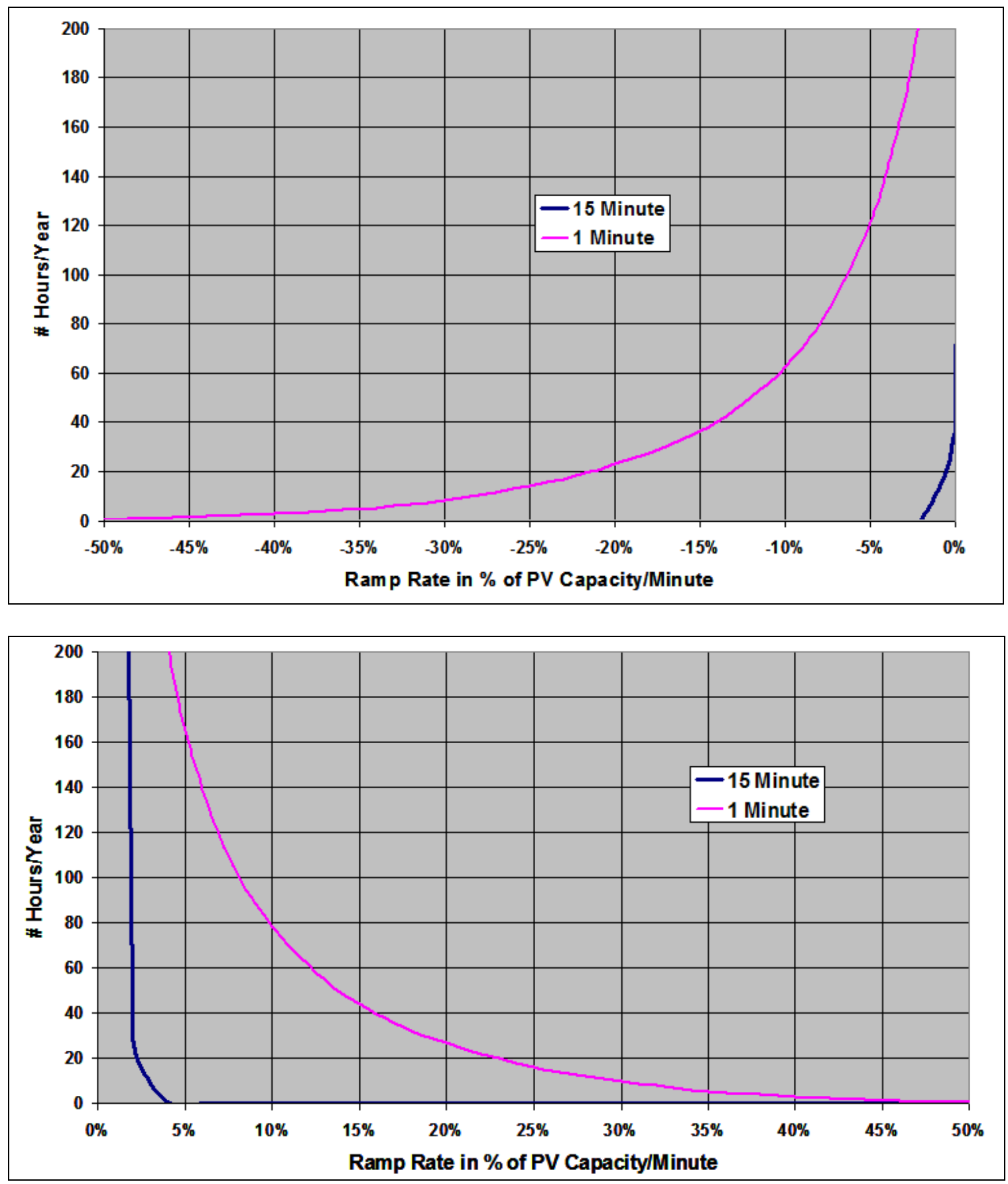

Figure 4-5. Cumulative frequency of PV ramp rates for year 2003, using 1-minute and 15minute solar radiation data from NREL/SRRL. Figure 4-5a (top) shows negative PV ramp rates, and Figure 4-4b (bottom) shows positive PV ramp rates.

This analysis demonstrates the possible significance of rapid fluctuations of PV power to grid stability. This effect obviously can be mitigated to some degree by distributing the PV systems over larger spatial extents. Examining the effect of these fluctuations over time and space will be the subject of RSI research at NREL in the near future. This research will require the use of high resolution PV output data such as from the $4.59 \mathrm{MW}$ PV system operated by Tucson Electric Power (Curtright and Apt 2007). Figure 4-6 
shows the power spectrum of the fluctuations from this system over 2 years using 1minute resolution data. The system occupies 44 acres (roughly 400 square meters on each side). The frequency response for subhourly fluctuations has a characteristic slope of about -1.3 (red line). The frequency response begins to "roll off" or drop below linear at a frequency of about $0.002 \mathrm{HZ}$, corresponding to a time constant of about 8 minutes. The power spectra for smaller subsets of the PV array roll off at higher frequencies.

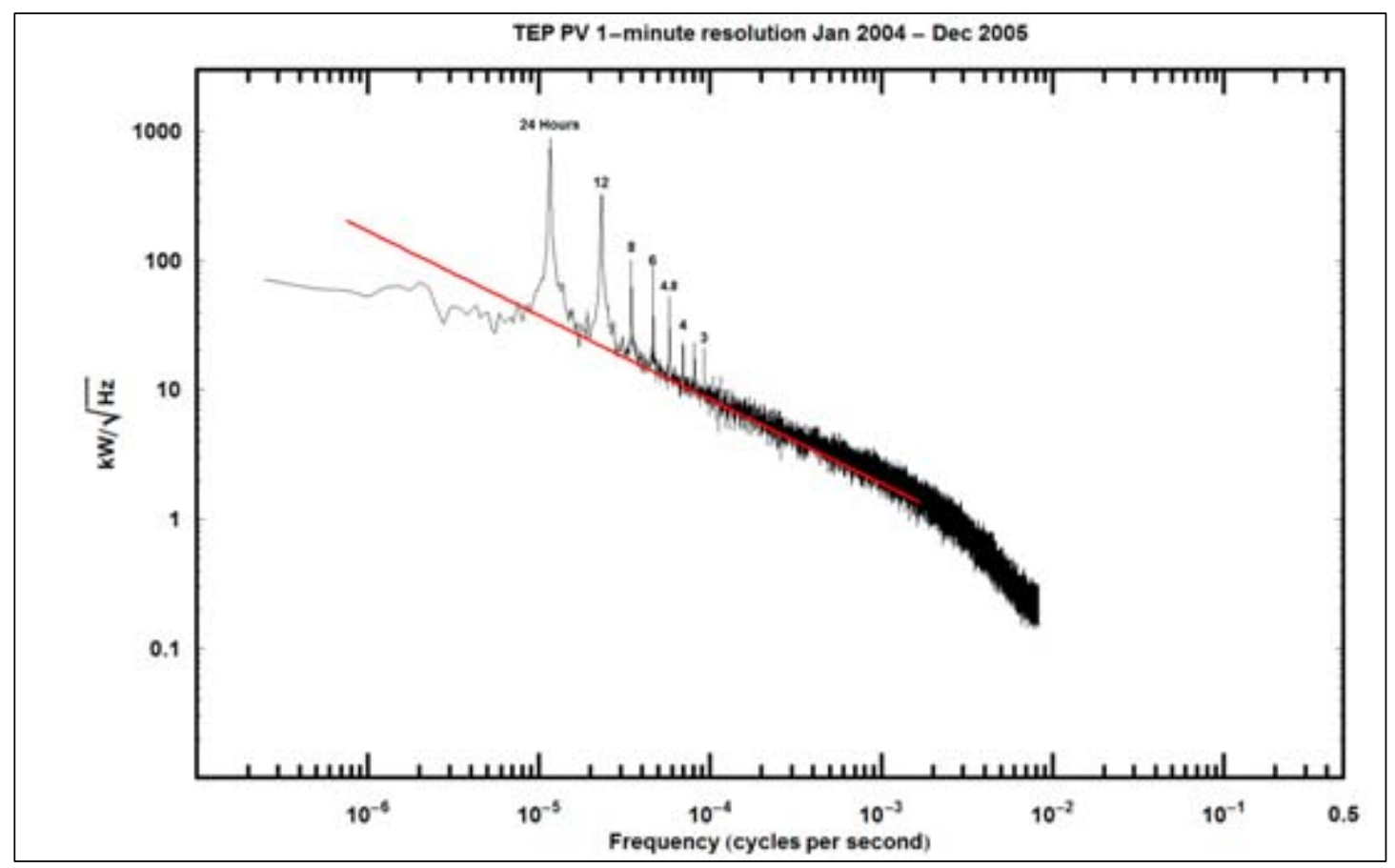

Figure 4-6. Power spectrum of PV output from Tucson Electric Power 4.59 MW PV plant at Springerville, Arizona. Two years (2004-2005) of data sampled at 1-minute interval (Curtright and Apt 2007).

NREL plans to use similar analyses of measured radiation data to assess the fluctuations in the solar resource (mostly due to transient clouds) at different locations and times of year, and in different climates. The PV system output analyses will guide NREL in choosing the data rates for new measurements.

Additional areas of interest will be the use of higher-resolution weather and solar radiation data for modeling of utility system loads, correlation with real and prospective PV system penetration, and the correlation of peak loads for summer air conditioning with solar electric generation. NREL regards this as a great opportunity for collaboration between utility system modelers, meteorologists, and geospatial scientists.

\subsection{Outreach}

Several avenues were pursued to solicit input from stakeholders and utility experts regarding anticipated needs. A questionnaire was developed to help crystallize the issues and focus attention on characteristics of the solar resource that affect grid integration. The questionnaire is included in Appendix C. 
The questionnaire was distributed at an energy efficiency workshop sponsored by the Bonneville Power Authority in May 2007. The questionnaire also was distributed and discussed at a meeting of the University of Oregon sponsors in Eugene, Oregon, in May 2007. Representatives of Pacific New Mexico Electric, who had visited NREL earlier in 2007 seeking information about renewable energy generation, also were given the questionnaire. Despite the widespread distribution these solicitations resulted in only one response, and it focused only on end-user deployment of technologies (availability of installers and lower prices of manufactured PV) rather than the specific issues of grid connectivity.

NREL organized a workshop at the annual conference of the American Solar Energy Society in Cleveland, Ohio, in July for the then newly released National Solar Radiation Data Base. About one-quarter of the workshop agenda was dedicated to soliciting information from attendees regarding the issues of grid integration of renewable technologies. Among the comments and suggestions from attendees were the following:

- Higher spatial resolution for solar data (finer than the currently available $10 \mathrm{~km}$ )

- Fifteen-minute time resolution or finer for solar data sets

- Solar resource forecasting

- Continued annual updates of the NSRDB

- A 1981 to 2011 30-year NSRDB product (period of conventional climatic norm)

- Need for spectral data (e.g., PV technology spectral sensitivities)

- Better estimates of aerosols for better model performance

- Interaction with international interests (i.e., the International Energy Agency)

- Analysis of geographical climate shifts due to global warming or other climate trends

- Wind assessment variability trends (e.g., 20-year period)

- Develop effects of El Niño regarding interannual variability

- Evaluate marginal sites for recent weather effects compared with long-term (100 year) effects

- Model improvements

- Long-term measurements for more accurate trends and model validation

- Include maximum and minimum values in TMY or other summary data for bestcase and worst-case scenarios (also could be mandatory for project funding analysis).

- Analyze correlations between wind and solar power to characterize the potential for complementary power production between wind and solar power.

- Incorporate caveats in resource characterization regarding the effects of anomalous but high-impact events (such as the eruption of Mt. Pinatubo). 


\subsection{Gap Analysis}

The analysis conducted in this study shows that there are questions of uncertainty and risk regarding our knowledge of weather and solar variability input to PV systems. Aspects of variability must be addressed to meet the needs of the electric utilities for improved engineering, deployment, and operation of solar energy conversion systems.

- High-resolution temporal data. Electrical generation by photovoltaic (PV) and solar thermal electric power systems is directly proportional to the available solar irradiance. Historical solar resource data are available for hourly time intervals. Sub-hourly (e.g., 15-minute) time-series data with dense spatial coverage are needed to address load-following simulations and related economic considerations. Because of the inherently fast response of solar energy conversion systems, it is possible that future needs for solar resource and associated weather data will be on the order of a few minutes or less.

- Site-specific resource data. The latest National Solar Radiation Data Base (NSRDB) along with the 1991-2005 update provides historical solar irradiance data for specific locations from 1961 to 2005 with a resulting spatial scale of about $100 \mathrm{~km}$. Additionally, based on satellite remote sensing model estimates the NSRDB provides solar irradiance data for $10-\mathrm{km}$ grid cells for the period from 1998 to 2005 . Characterizing the spatial variability of solar irradiance over distances of $1 \mathrm{~km}$ or less is important for improving the siting, design, and performance monitoring of a solar energy conversion system (i.e., distributed PV generation at the community or sub-grid level). Data from large PV systems that could have high-quality radiometric instrumentation need to be systematically investigated.

- Solar resource forecasting. Utility operations require forecasting capabilities over a variety of time steps ranging from very short term (1-3 hour) for dispatching, day-ahead for system operations, and seasonal and interannual for long-term system planning and economic analyses. Currently there are no operational forecasts for solar irradiance meeting these needs.

- Interactive data archive. End users of solar resource data must be able to access historical and nearly real-time solar resource information. The ability to create specific query-based data sets will help system designers, analysts, and system operators achieve optimum performance from solar energy conversion systems.

- Low-cost solar radiation instrumentation. Needs for higher spatial and temporal resolution solar resource data, including plane-of-array irradiance, could be addressed by a variety of commercially available radiometers and data acquisition systems, and the development and characterization of a radiometer system, depending on the required measurement uncertainty limits. These measurement systems could also be deployed at existing PV installations or other strategically important or climatologically significant locations to collect performance data and validate solar radiation models. 
- Improved satellite-derived data sets. Existing methods for estimating surface solar irradiance from satellite imagery can be improved to account for temporal variations of clouds and atmospheric aerosols to increase the model accuracy from the present nominal value $+/-20 \%$ for hourly estimates. This work likely will include better discrimination between snow cover and clouds to improve model performance in many geographical locations and seasons.

- Need for cross-disciplinary analysis projects. The use of solar resource and meteorological data to address complex problems such as time-dependent utility load estimations, cloud transient effects on grid stability, and solar dispatching require close collaboration between analysts and utility planners, and the resource and meteorology community. Simply providing a one-way flow of data to the analysts is not sufficient.

The Solar Resource Assessment activity within the RSI addresses these gaps needs through two major areas: solar resource forecasting, and current and historical data characterization. 


\subsection{Conclusions and Recommendations}

This report provides a summary of existing information on solar resources pertinent to large-scale grid-tied distributed PV applications. The report shows that, although there is a strong understanding of current large and medium spatial scale solar resources in the United States, the resolution of the information in many ways is inadequate for distributed PV analyses. For example, high-quality ground measurement stations that can provide adequate time series information (15-minutes or less) are very limited in number, and many locations around the United States are not represented by any ground measurements at all.

Modeled data such as the new National Solar Radiation Data Base can provide uniform spatial coverage across the country, but is limited to hourly time series data. Analyses of these data, undertaken as part of this study, show that interannual variability and uncertainties in modeling approaches, as well as complications associated with changes in the way ground-based routine weather observations have been collected in this country over the past two decades, and that simulation results of grid-tied PV systems are dependent on the choice of year (or years) for conducting the simulations. The assessment of current information also shows that there is no reliable operational shortterm solar resource forecasting ( 1 to 3 days ahead) available to system operators and utilities for better understanding of dispatching and load following predictions of distributed PV systems.

As a result of these studies, a gap analysis was conducted that highlighted 6 key areas in which future research programs are required:

- A need for high-resolution (15-minutes or less) resource data derived from the hourly model results, and/or from additional high-quality measurement stations.

- A need for ways to obtain more-reliable site-specific data, either from extrapolation methods or from more spatially refined satellite-derived solar resource estimates, or (ideally) from on-site measurements.

- A need for day-ahead to 3-day ahead solar resource forecasts, as well as very short term (1-3 hour) and seasonal and internanual forecasts, for use by system operators in system planning and load-following operations.

- A need for an interactive archive of solar resource information so that developers, utilities, system operators, and system planners can access the types of solar resource needed for specific analyses and applications.

- Low-cost instrumentation for easier and more-0affordable solar resource assessment at key locations.

- Improved satellite data sets through improved estimates of aerosols, a better detection of snow cover, and higher spatial resolution where required.

Based on the assessment of current resource availability and the future needs by utilities, system operators, and industry involved in large-scale grid-tied PV applications, a 5-year solar resource assessment research plan was prepared to address closing the identified 
gaps. The research plan places particular emphasis on updating and improving the reliability of the National Solar Radiation Data Base, improving techniques for measuring and simulating short-term time series data, and developing operation short-term solar resource forecasting techniques. 


\subsection{References}

Ackerman, T.P.; Stokes, G.M. (2003). "The Atmospheric Radiation Measurement Program.” Physics Today (56:1); pp. 38-44.

Augustine, J.A.; DeLuisi, J.J.; Long, C.N. (2000). SURFRAD—_AA National Surface Radiation Budget Network for Atmospheric Research". Bulletin of the American Meteorological Society (81); pp. 2341-2357.

Curtright, A.E.; Apt, J. (2007). "The Character of Power Output from Utility-Scale Photovoltaic Systems," Carnegie Mellon Electricity Industry Center Working Paper CEIC-07-05.

George, R.;.Wilcox, S; Anderberg, M.; George, R.; Perez, R. (2007). "National Solar Radiation Database (NSRDB)—10 Km Gridded Hourly Solar Database." Proceedings Solar 2007 Cleveland OH. Boulder, CO: American Solar Energy Society.

Graumann, A. (2003). Data Documentation for Dataset 3701, GOES Data User's Guide, ver. 1.1. Ashville, NC: National Climatic Data Center.

Hicks, B.B.; Deluisi, J.J.; Matt, D.R. (1996). “The NOAA Integrated Surface Irradiance Study (ISIS) - A New Surface Radiation Monitoring Program." Bulletin of the American Meteorological Society (77:12); pp. 2857-2864.

Maxwell, E. L. (1998). "METSTAT The Solar Radiation Model Used in the Production of the National Solar Radiation Data Base (NSRDB)." Solar Energy (62:4); pp. 263-79.

Marion, W.; Urban, K. (1995). User's Manual for TMY2s Typical Meteorological Years. Golden, CO: National Renewable Energy Laboratory.

Moore, L.; Cameron, C. (2007). "System Modeling and Performance Database Development." Proceedings 2007 DOE Solar Energy Technology Program Review, Denver, $C O$.

Myers, D.; Wilcox, S.; Marion, W.; George, R.; Anderberg, M. (2005). "Broadband Model Performance for an Updated National Solar Radiation Database in the United States of America." Proceedings 2005 Solar World Congress. International Solar Energy Society.

National Renewable Energy Laboratory (1995). Final Technical Report National Solar Radiation Data Base (1961-1990) NREL TP-463-5784. Golden, CO: National Renewable Energy Laboratory.

Ohmura A. et. al. (1998). "Baseline Surface Radiation Network (BSRN/WRMC), a new precision radiometry for climate research." Bulletin of the American Meteorological Society (79); pp. 2115-2136. 
Perez, R.; Bonaventura-Sparagna, J.; Kmiecik, M.; George, R.; Renné, D. (2001). "Cloud Cover Reporting Bias at Major Airports.” Proceedings of Forum 2001 Solar Energy: The Power to Choose; Including Proceedings of ASES Annual Conference and Proceedings of the 26th National Passive Solar Conference, 21-25 April 2001, Washington, DC. NREL/CP-560-32960. Boulder, CO: American Solar Energy Society; Washington, DC: American Institute of Architects Committee on the Environment; pp. 319-323.

Perez, R.; Ineichen, P.; Moore, K.; Kmiecikm, M.; Chain, C.; George, R.; Vignola, F. (2002). “A New Operational Satellite-to-Irradiance Model.” Solar Energy (73:5); pp. 307-317.

Perez, R.; Wilcox, S.; Renné, D.; Moore, K.; Zelenka, A. (2007). “Forecasting Solar Radiation, Preliminary Evaluation of an Approach Based upon the National Forecast Database.” Solar Energy (81:6); pp. 809-812.

Renné, D.; Stoffel, T.; Anderberg, M.; Gray-Hann, P.; Augustyn, J. (2000). "Current Status of Solar Measurement Programs in the U.S." Campbell-Howe, R., ed. Proceedings of the Solar 2000 Conference Including Proceedings of ASES Annual Conference and Proceedings of the 25th National Passive Solar Conference, 16-21 June 2000, Madison, Wisconsin. NREL/CP-560-28115. Boulder, CO: American Solar Energy Society; Washington, DC: American Institute of Architects Committee on the Environment.

Stoffel, T. L. (1987). HBCU Solar Radiation Network Annual Report: FY 1986. NREL/PR-215-3098. Golden, CO: National Renewable Energy Laboratory.

United States Department of Energy (1996). Science Plan for the Atmospheric Radiation Measurement (ARM) Program. DOE/ER-0670T, Washington, DC.

University of Oregon (1999). Pacific Northwest Solar Radiation Data. Eugene, OR: Physics Department, Solar Energy Center, University of Oregon.

Whitlock, C.H.; Brown, D.E.; Chandler, W.S.; DiPasquale, R.C.; Gupta, S.K.; Wilber, A.C.; Ritchey, N.A.; Kratz, D.P.; Stackhouse, P.W. (2001). "Global Solar Energy Anomalies Including El Nino and La Nina Years." ASME Journal of Solar Energy Engineering (23:3); pp. 211-215.

Wilcox, S. (2007). National Solar Radiation Database 1991-2005 Update: User's Manual. NREL/TP-581-41364. Golden, CO: National Renewable Energy Laboratory.

Wilcox, S.; Anderberg, M.; Beckman, W.; DeGetanon, A.; George, R.; Gueymard, C.; Marion, W.; Myers, D.; Perez, R.; Plantico, M.; Renen, D.; Stackhouse, P.; Vignola, F. (2005). "Progress on an Updated National Solar Radiation Database for the United States." Proceedings Solar World Congress 2005, Orlando, FL. Boulder, CO: International Solar Energy Society.

Wilcox, S.; Anderberg, M.; George, R.; Marion, W.; Myers, D.; Renne, D.; Lott, N.; Whitehurst, T.; Beckman, W.; Gueymard, C.; Perez, R.; Stackhouse, P.; Vignola, F. (2007). "Completing Production of the Updated National Solar Radiation Database for 
the United States." Proceedings Solar 2007, Cleveland OH. Boulder, CO: American Solar Energy Society. 


\subsection{Appendices}

\section{Appendix A—NSRDB Data Fields}

Table A-1. NSRDB Data Fields

\begin{tabular}{|c|c|c|c|c|}
\hline Field & Element & Unit & Resolution & Description \\
\hline 1 & Date & YYYY-MM-DD & - & Date of data record \\
\hline 2 & Time & $\mathrm{HH}: \mathrm{MM}$ & - & $\begin{array}{l}\text { Time of data record (local standard } \\
\text { time) }\end{array}$ \\
\hline 3 & $\begin{array}{l}\text { Hourly mean zenith angle } \\
\text { (for sunup periods) }\end{array}$ & $\begin{array}{l}\text { Decimal } \\
\text { degree }\end{array}$ & $0.1^{\circ}$ & $\begin{array}{l}\text { Solar zenith angle (angle between } \\
\text { sun and the zenith) as the mean of } \\
\text { all } 1 \text {-minute sunup zenith angle } \\
\text { values for the } 60 \text {-minute period } \\
\text { ending at the timestamp }\end{array}$ \\
\hline 4 & $\begin{array}{l}\text { Hourly mean azimuth } \\
\text { angle (for sunup periods) }\end{array}$ & $\begin{array}{l}\text { Decimal } \\
\text { degree }\end{array}$ & $0.1^{\circ}$ & $\begin{array}{l}\text { Solar azimuth angle (angle between } \\
\text { sun and north) as the mean of all } 1- \\
\text { minute sunup azimuth angle values } \\
\text { for the } 60 \text {-minute period ending at } \\
\text { the timestamp }\end{array}$ \\
\hline 5 & $\begin{array}{l}\text { Hourly extraterrestrial } \\
\text { radiation on a horizontal } \\
\text { surface }\end{array}$ & $\begin{array}{l}\text { Watt-hour per } \\
\text { square meter }\end{array}$ & $1 \mathrm{Wh} / \mathrm{m}^{2}$ & $\begin{array}{l}\text { Amount of solar radiation received } \\
\text { on a horizontal surface at the top of } \\
\text { the atmosphere during the } \\
60 \text {-minute period ending at the } \\
\text { timestamp }\end{array}$ \\
\hline 6 & $\begin{array}{l}\text { Hourly extraterrestrial } \\
\text { radiation normal to the } \\
\text { sun }\end{array}$ & $\begin{array}{l}\text { Watt-hour per } \\
\text { square meter }\end{array}$ & $1 \mathrm{Wh} / \mathrm{m}^{2}$ & $\begin{array}{l}\text { Amount of solar radiation received } \\
\text { on a surface normal to the sun at } \\
\text { the top of the atmosphere during } \\
\text { the } 60 \text {-minute period ending at the } \\
\text { timestamp }\end{array}$ \\
\hline 7 & Modeled global horizontal & $\begin{array}{l}\text { Watt-hour per } \\
\text { square meter }\end{array}$ & $1 \mathrm{Wh} / \mathrm{m}^{2}$ & $\begin{array}{l}\text { Total amount of direct and diffuse } \\
\text { solar radiation (modeled) received } \\
\text { on a horizontal surface during the } \\
60 \text {-minute period ending at the } \\
\text { timestamp }\end{array}$ \\
\hline 8 & $\begin{array}{l}\text { Modeled global horizontal } \\
\text { source flag }\end{array}$ & & - & \\
\hline 9 & $\begin{array}{l}\text { Modeled global horizontal } \\
\text { uncertainty }\end{array}$ & $\pm \%$ & $1 \%$ & \\
\hline 10 & Modeled direct normal & $\begin{array}{l}\text { Watt-hour per } \\
\text { square meter }\end{array}$ & $1 \mathrm{Wh} / \mathrm{m}^{2}$ & $\begin{array}{l}\text { Amount of solar radiation (modeled) } \\
\text { received in a collimated beam on a } \\
\text { surface normal to the sun during the } \\
60 \text {-minute period ending at the } \\
\text { timestamp }\end{array}$ \\
\hline 11 & $\begin{array}{l}\text { Modeled direct normal } \\
\text { source flag }\end{array}$ & & - & \\
\hline 12 & $\begin{array}{l}\text { Modeled direct normal } \\
\text { uncertainty }\end{array}$ & $\pm \%$ & $1 \%$ & \\
\hline
\end{tabular}




\begin{tabular}{|c|c|c|c|c|}
\hline Field & Element & Unit & Resolution & Description \\
\hline 13 & $\begin{array}{l}\text { Modeled diffuse } \\
\text { horizontal }\end{array}$ & $\begin{array}{l}\text { Watt-hour per } \\
\text { square meter }\end{array}$ & $1 \mathrm{Wh} / \mathrm{m}^{2}$ & $\begin{array}{l}\text { Amount of solar radiation (modeled) } \\
\text { received from the sky (excluding the } \\
\text { solar disk) on a horizontal surface } \\
\text { during the } 60 \text {-minute period ending } \\
\text { at the timestamp }\end{array}$ \\
\hline 14 & $\begin{array}{l}\text { Modeled diffuse } \\
\text { horizontal source flag }\end{array}$ & & - & \\
\hline 15 & $\begin{array}{l}\text { Modeled diffuse } \\
\text { horizontal uncertainty }\end{array}$ & $\pm \%$ & $1 \%$ & \\
\hline 16 & $\begin{array}{l}\text { Measured global } \\
\text { horizontal }\end{array}$ & $\begin{array}{l}\text { Watt-hour per } \\
\text { square meter }\end{array}$ & $1 \mathrm{Wh} / \mathrm{m}^{2}$ & $\begin{array}{l}\text { Total amount of direct and diffuse } \\
\text { solar radiation received on a } \\
\text { horizontal surface during the } \\
60 \text {-minute period ending at the } \\
\text { timestamp }\end{array}$ \\
\hline 17 & $\begin{array}{l}\text { Measured global } \\
\text { horizontal quality flag }\end{array}$ & SERI-QC & - & \\
\hline 18 & Measured direct normal & $\begin{array}{l}\text { Watt-hour per } \\
\text { square meter }\end{array}$ & $1 \mathrm{Wh} / \mathrm{m}^{2}$ & $\begin{array}{l}\text { Amount of solar radiation received } \\
\text { in a collimated beam on a surface } \\
\text { normal to the sun during the } \\
60 \text {-minute period ending at the } \\
\text { timestamp }\end{array}$ \\
\hline 19 & $\begin{array}{l}\text { Measured direct normal } \\
\text { quality flag }\end{array}$ & SERI-QC & - & \\
\hline 20 & $\begin{array}{l}\text { Measured diffuse } \\
\text { horizontal }\end{array}$ & $\begin{array}{l}\text { Watt-hour per } \\
\text { square meter }\end{array}$ & $1 \mathrm{Wh} / \mathrm{m}^{2}$ & $\begin{array}{l}\text { Amount of solar radiation received } \\
\text { from the sky (excluding the solar } \\
\text { disk) on a horizontal surface during } \\
\text { the } 60 \text {-minute period ending at the } \\
\text { timestamp }\end{array}$ \\
\hline 21 & $\begin{array}{l}\text { Measured diffuse } \\
\text { horizontal quality flag }\end{array}$ & SERI-QC & - & \\
\hline 22 & ${ }^{*}$ Total sky cover & Tenth of sky & 1 tenth & $\begin{array}{l}\text { Amount of sky dome covered by } \\
\text { clouds or obscuring phenomena at } \\
\text { the time indicated }\end{array}$ \\
\hline 23 & ${ }^{*}$ Total sky cover flag & & - & \\
\hline 24 & *Opaque sky cover & Tenth of sky & 1 tenth & $\begin{array}{l}\text { Amount of sky dome covered by } \\
\text { clouds or obscuring phenomena } \\
\text { that prevent observing the sky or } \\
\text { higher cloud layers at the time } \\
\text { indicated }\end{array}$ \\
\hline 25 & *Opaque sky cover flag & & - & \\
\hline 26 & ${ }^{*}$ Dry-bulb temperature & Degree C & $0.1^{\circ}$ & $\begin{array}{l}\text { Dry-bulb temperature at the time } \\
\text { indicated }\end{array}$ \\
\hline 27 & $\begin{array}{l}\text { *Dry-bulb temperature } \\
\text { flag }\end{array}$ & & - & \\
\hline 28 & ${ }^{*}$ Dew-point temperature & Degree C & $0.1^{\circ}$ & $\begin{array}{l}\text { Dew-point temperature at the time } \\
\text { indicated }\end{array}$ \\
\hline 29 & $\begin{array}{l}\text { *Dew-point temperature } \\
\text { flag }\end{array}$ & & - & \\
\hline
\end{tabular}




\begin{tabular}{|c|c|c|c|c|}
\hline Field & Element & Unit & Resolution & Description \\
\hline 30 & ${ }^{*}$ Relative humidity & Percent & $1 \%$ & $\begin{array}{l}\text { Relative humidity at the time } \\
\text { indicated }\end{array}$ \\
\hline 31 & ${ }^{*}$ Relative humidity flag & & - & \\
\hline 32 & ${ }^{*}$ Station pressure & Millibar & $1 \mathrm{mbar}$ & $\begin{array}{l}\text { Station pressure at the time } \\
\text { indicated }\end{array}$ \\
\hline 33 & ${ }^{*}$ Station pressure flag & & - & \\
\hline 34 & *Wind speed & Meter/second & $0.1 \mathrm{~m} / \mathrm{s}$ & Wind speed at the time indicated \\
\hline 35 & ${ }^{*}$ Wind speed flag & & - & \\
\hline 36 & *Wind direction & $\begin{array}{l}\text { Degrees from } \\
\text { north } \\
\left(360^{\circ}=\text { north; }\right. \\
0^{\circ}=\text { undefined) }\end{array}$ & $10^{\circ}$ & Wind direction at the time indicated \\
\hline 37 & *Wind direction flag & & - & \\
\hline 38 & Horizontal visibility & Meter & $1 \mathrm{~m}$ & $\begin{array}{l}\text { Distance to discernable remote } \\
\text { objects at the time indicated }\end{array}$ \\
\hline 39 & Horizontal visibility flag & & - & \\
\hline 40 & ${ }^{*}$ Ceiling height & Meter & $1 \mathrm{~m}$ & $\begin{array}{l}\text { Height of the cloud base above } \\
\text { local terrain }\end{array}$ \\
\hline 41 & ${ }^{*}$ Ceiling height flag & & - & \\
\hline 42 & Liquid precipitation depth & Millimeter & $1 \mathrm{~mm}$ & $\begin{array}{l}\text { The amount of liquid precipitation } \\
\text { observed at the indicated time for } \\
\text { the period indicated in the liquid } \\
\text { precipitation quantity field }\end{array}$ \\
\hline 43 & $\begin{array}{l}\text { Liquid precipitation depth } \\
\text { flag }\end{array}$ & & - & \\
\hline 44 & $\begin{array}{l}\text { Liquid precipitation } \\
\text { quantity }\end{array}$ & Hour & $1 \mathrm{hr}$ & $\begin{array}{l}\text { The period of accumulation for the } \\
\text { liquid precipitation depth field }\end{array}$ \\
\hline 45 & $\begin{array}{l}\text { Liquid precipitation } \\
\text { quantity flag }\end{array}$ & & - & \\
\hline 46 & ${ }^{*}$ Precipitable water & Centimeter & $0.1 \mathrm{~cm}$ & $\begin{array}{l}\text { The total precipitable water } \\
\text { contained in a column of unit cross } \\
\text { section extending all of the way } \\
\text { from the earth's surface to the "top" } \\
\text { of the atmosphere }\end{array}$ \\
\hline 47 & ${ }^{*}$ Precipitable water flag & & - & \\
\hline 48 & $\begin{array}{l}\text { *Aerosol optical depth, } \\
\text { broadband }\end{array}$ & [Unitless] & 0.001 & $\begin{array}{l}\text { The broadband optical depth per } \\
\text { unit of airmass due to extinction by } \\
\text { the aerosol component of the } \\
\text { atmosphere }\end{array}$ \\
\hline 49 & $\begin{array}{l}{ }^{*} \text { Aerosol optical depth } \\
\text { broadband flag }\end{array}$ & & - & \\
\hline
\end{tabular}

\footnotetext{
${ }^{*}$ Asterisks indicate that a field is subject to data filling.
} 


\section{Appendix B-Sources of Measured Solar Radiation}

Instrumentation details vary across the networks and even at specific sites. This information can be obtained from the websites for each of these networks.

Table B-1. SURFRAD Stations

\begin{tabular}{lccc}
\hline Station Name & Latitude, Longitude & Elevation $(\mathbf{m})$ & Period of Record \\
\hline Bondville (IL) & $40.06 \mathrm{~N}, 88.37 \mathrm{~W}$ & 213 & 1995 to present \\
Desert Rock (NV) & $36.626 \mathrm{~N}, 116.018 \mathrm{~W}$ & 1,007 & 1998 to present \\
Fort Peck (MT) & $48.31 \mathrm{~N}, 105.10 \mathrm{~W}$ & 634 & 1995 to present \\
Goodwin Creek (MS) & $34.25 \mathrm{~N}, 89.87 \mathrm{~W}$ & 98 & 1995 to present \\
Penn State (PA) & $40.72 \mathrm{~N}, 77.93 \mathrm{~W}$ & 376 & 1998 to present \\
Sioux Falls (SD) & $43.73 \mathrm{~N}, 96.62 \mathrm{~W}$ & 473 & 2003 to present \\
Table Mountain (CO) & $40.125 \mathrm{~N}, 105.237 \mathrm{~W}$ & 1,689 & 1995 to present \\
\hline
\end{tabular}

* The Desert Rock station was converted from an ISIS station in 1998.

Table B-2. ISIS Stations

\begin{tabular}{lccc}
\hline Station Name & Latitude, Longitude & Elevation $(\mathbf{m})$ & Period of Record \\
\hline Albuquerque (NM) & $35.04 \mathrm{~N}, 106.62 \mathrm{~W}$ & 1,617 & 1995 to present \\
Bismarck (ND) & $46.77 \mathrm{~N}, 100.77 \mathrm{~W}$ & 503 & 1994 to present \\
Desert Rock (NV) & $36.62 \mathrm{~N}, 116.02 \mathrm{~W}$ & 1,007 & 1995 to $1998^{*}$ \\
Hanford (CA) & $36.31 \mathrm{~N}, 119.63 \mathrm{~W}$ & 73 & 1995 to present \\
Madison (WI) & $43.13 \mathrm{~N}, 89.33 \mathrm{~W}$ & 271 & 1996 to present \\
Oak Ridge (TN) & $35.96 \mathrm{~N}, 84.29 \mathrm{~W}$ & 334 & 1995 to 2007 \\
Salt Lake City (UT) & $40.77 \mathrm{~N}, 111.97 \mathrm{~W}$ & 1,288 & 1995 to present \\
Seattle (WA) & $46.68 \mathrm{~N}, 122.25 \mathrm{~W}$ & 20 & 1995 to present \\
Sterling (VA) & $38.98 \mathrm{~N}, 77.47 \mathrm{~W}$ & 85 & 1995 to present \\
Tallahassee (FL) & $30.38 \mathrm{~N}, 84.37 \mathrm{~W}$ & 18 & 1995 to 2002 \\
\hline
\end{tabular}

* Desert Rock was converted to a SURFRAD station in 1998.

Table B-3. University of Oregon Network Stations

\begin{tabular}{lccc}
\hline Station Name & Latitude, Longitude & Elevation $(\mathbf{m})$ & Period of Record \\
\hline Aberdeen (ID)* $^{*}$ & $42.95 \mathrm{~N}, 112.78 \mathrm{~W}$ & 1,433 & 1994 to present \\
Ashland (OR) $^{*}$ & $42.19 \mathrm{~N}, 122.70 \mathrm{~W}$ & 595 & 2000 to present \\
Bend (OR) & $43.99 \mathrm{~N}, 121.35 \mathrm{~W}$ & 1,100 & 1977 to present \\
Bend [PV] & $44.06 \mathrm{~N}, 121.31 \mathrm{~W}$ & 1,124 & 2004 to present \\
Boise (ID) & $43.62 \mathrm{~N}, 116.21 \mathrm{~W}$ & 701 & 1994 to present \\
Burns (OR) & $43.52 \mathrm{~N}, 119.02 \mathrm{~W}$ & 1,265 & 1979 to present \\
Cannon Beach [PV] (OR) & $45.895 \mathrm{~N}, 123.963 \mathrm{~W}$ & 30 & 2003 to present \\
Cheney (WA) & $47.490 \mathrm{~N}, 117.589 \mathrm{~W}$ & 777 & 2000 to present \\
Christmas Valley (OR) & $43.24 \mathrm{~N}, 120.88 \mathrm{~W}$ & 1,325 & 1994 to present \\
Coeur d'Alene (ID) & $47.72 \mathrm{~N}, 116.78 \mathrm{~W}$ & 674 & 1982 to 1986 \\
Coos Bay (OR) & $43.35 \mathrm{~N}, 124.34 \mathrm{~W}$ & 10 & 1988 to present \\
Corvallis (OR) & $44.57 \mathrm{~N}, 123.23 \mathrm{~W}$ & 65 & 1980 to 1982 \\
Dillon (MT) & $45.21 \mathrm{~N}, 112.64 \mathrm{~W}$ & 1,590 & 2002 to present \\
Eugene (OR)* & $44.05 \mathrm{~N}, 123.07 \mathrm{~W}$ & 150 & 1975 to present \\
Forest Grove (OR) & $45.55 \mathrm{~N}, 123.08 \mathrm{~W}$ & 55 & 1997 to present \\
Grants Pass [PV] (OR)* & $42.44 \mathrm{~N}, 123.35 \mathrm{~W}$ & 293 & 2003 to present \\
Green River (WY) & $41.46 \mathrm{~N}, 109.44 \mathrm{~W}$ & 1,000 & 1994 to present \\
Hermiston (OR)* & $45.82 \mathrm{~N}, 119.28 \mathrm{~W}$ & 180 & 1979 to present \\
Hood River (OR) & $45.70 \mathrm{~N}, 121.52 \mathrm{~W}$ & 140 & 1984 to 1988
\end{tabular}




\begin{tabular}{lccc}
\hline Station Name & Latitude, Longitude & Elevation $(\mathbf{m})$ & Period of Record \\
\hline Klamath Falls (OR) $^{*}$ & $42.22 \mathrm{~N}, 121.74 \mathrm{~W}$ & 1,220 & 1998 to present \\
Klamath Falls [PV] (OR)* & $42.26 \mathrm{~N}, 121.78 \mathrm{~W}$ & 1,351 & 2003 to 2006 \\
La Grande (OR) & $45.33 \mathrm{~N}, 118.08 \mathrm{~W}$ & 885 & 1977 to 1984 \\
Madras (OR)* & $44.69 \mathrm{~N}, 121.16 \mathrm{~W}$ & 997 & 1994 to present \\
Medford (OR) & $42.37 \mathrm{~N}, 122.87 \mathrm{~W}$ & 396 & 1977 to 1980 \\
Moab (UT) & $38.58 \mathrm{~N}, 109.54 \mathrm{~W}$ & 1,000 & 1994 to present \\
Parma (ID)* & $43.80 \mathrm{~N}, 116.94 \mathrm{~W}$ & 678 & 1994 to present \\
Picabo (ID) & $43.31 \mathrm{~N}, 114.17 \mathrm{~W}$ & 1,472 & 1994 to present \\
Portland (OR) & $45.40 \mathrm{~N}, 122.58 \mathrm{~W}$ & 98 & 1980 to present \\
Portland [PV] (OR) & $45.51 \mathrm{~N}, 122.69 \mathrm{~W}$ & 70 & 2004 to present \\
Richland (WA) & $46.32 \mathrm{~N}, 119.28 \mathrm{~W}$ & 130 & 1993 to 1996 \\
Salem [PV] (OR) & $44.94 \mathrm{~N}, 123.03 \mathrm{~W}$ & 60 & 2003 to present \\
Seattle (OR) & $47.68 \mathrm{~N}, 122.25 \mathrm{~W}$ & 20 & 1995 to present \\
Sheldon Village (OR) & $44.05 \mathrm{~N}, 123.07 \mathrm{~W}$ & 150 & 2002 to present \\
Silver Lake (OR) & $43.12 \mathrm{~N}, 121.06 \mathrm{~W}$ & 1,355 & 2002 to present \\
Twin Falls (ID)* & $42.55 \mathrm{~N}, 114.35 \mathrm{~W}$ & 1,200 & 1980 to present \\
Whitehorse Ranch (OR) & $42.33 \mathrm{~N}, 118.23 \mathrm{~W}$ & 1,325 & 1979 to 1985 \\
Willamette HS (OR) & $44.08 \mathrm{~N}, 123.07 \mathrm{~W}$ & 140 & 2002 to present \\
\hline
\end{tabular}

${ }^{*}$ Site measures meteorological parameters in addition to temperature.

Table B-4. University of Texas Solar Radiation Network

\begin{tabular}{lccc}
\hline Station Name & Latitude, Longitude & Elevation $(\mathbf{m})$ & Period of Record \\
\hline Abilene & $32.47 \mathrm{~N}, 99.71 \mathrm{~W}$ & 530 & 1997 to 2003 \\
Austin & $30.29 \mathrm{~N}, 97.74 \mathrm{~W}$ & 213 & 1985 to 2003 \\
Big Spring & $32.21 \mathrm{~N}, 101.53 \mathrm{~W}$ & 774 & 1996 to 2000 \\
Canyon & $34.99 \mathrm{~N}, 101.9 \mathrm{~W}$ & 1,068 & 1997 to 2003 \\
Clear Lake-NASA & $29.57 \mathrm{~N}, 95.09 \mathrm{~W}$ & 6 & 1997 to 2003 \\
Corpus Christi-Calallen & $27.88 \mathrm{~N}, 97.63 \mathrm{~W}$ & 6 & 1997 to 2003 \\
Del Rio & $29.38 \mathrm{~N}, 100.91 \mathrm{~W}$ & 308 & 1998 to 2001 \\
Edinburg & $26.31 \mathrm{~N}, 98.17 \mathrm{~W}$ & 30 & 1997 to 2003 \\
El Paso & $31.77 \mathrm{~N}, 106.5 \mathrm{~W}$ & 1,186 & 1997 to 2003 \\
Laredo & $27.57 \mathrm{~N}, 99.49 \mathrm{~W}$ & 142 & 1996 to 2003 \\
Menard & $30.91 \mathrm{~N}, 99.79 \mathrm{~W}$ & 582 & 1996 to 2003 \\
Overton & $32.29 \mathrm{~N}, 94.98 \mathrm{~W}$ & 146 & 1996 to 2003 \\
Pecos & $31.38 \mathrm{~N}, 103.63 \mathrm{~W}$ & 829 & 1996 to 2002 \\
Presidio & $29.55 \mathrm{~N}, 104.36 \mathrm{~W}$ & 783 & 1996 to 2002 \\
Sanderson & $30.15 \mathrm{~N}, 102.41 \mathrm{~W}$ & 817 & 1996 to 2002 \\
\hline
\end{tabular}

Table B-5. HBC/CONFRMM and Other Sites

\begin{tabular}{lccc}
\hline Station Name & Latitude, Longitude & Elevation (m) & Period of Record \\
\hline Bethune-Cookman College (FL) & $29.18 \mathrm{~N}, 81.02 \mathrm{~W}$ & 20 & 1985 to 1996 \\
Bluefield State College (WV) & $37.27 \mathrm{~N}, 81.24 \mathrm{~W}$ & 803 & 1985 to present \\
Elizabeth City State University (NC) & $36.28 \mathrm{~N}, 76.22 \mathrm{~W}$ & 26 & 1985 to present \\
Florida Solar Energy Center (FL) & $29.39 \mathrm{~N}, 80.76 \mathrm{~W}$ & 18 & 1998 to present \\
Johnson Space Center (TX) & $29.56 \mathrm{~N}, 95.12 \mathrm{~W}$ & 33 & 1997 to 2003 \\
Mississippi Valley State College (MS) & $33.50 \mathrm{~N}, 90.33 \mathrm{~W}$ & 52 & 1985 to 1996 \\
NREL Solar Radiation Research & $39.74 \mathrm{~N}, 105.18 \mathrm{~W}$ & 1,829 & 1981 to present \\
Laboratory (CO) & &
\end{tabular}




\begin{tabular}{lccc}
\hline Station Name & Latitude, Longitude & Elevation (m) & Period of Record \\
\hline Phoenix Federal Correctional & $33.83 \mathrm{~N}, 112.17 \mathrm{~W}$ & 340 & 2002 to present \\
Institute (AZ) & $32.03 \mathrm{~N}, 81.07 \mathrm{~W}$ & 11 & 1985 to 1996 \\
Savannah State College (GA) & $39.27 \mathrm{~N}, 105.62 \mathrm{~W}$ & 2,944 & 1977 to present \\
South Park (CO) & $32.27 \mathrm{~N}, 106.74 \mathrm{~W}$ & 1,201 & 1998 to 2000 \\
Southwest Technology Development & $36.06 \mathrm{~N}, 115.08 \mathrm{~W}$ & 615 & 2006 to present \\
Institute (NM) & $30.29 \mathrm{~N}, 97.74 \mathrm{~W}$ & 213 & 1997 to 2003 \\
University of Nevada, Las Vegas (NV) & $31.80 \mathrm{~N}, 106.40 \mathrm{~W}$ & 1,219 & 1997 to 2003 \\
University of Texas, Austin (TX) & $26.20 \mathrm{~N}, 98.22 \mathrm{~W}$ & 30 & 1997 to 2003 \\
University of Texas El Paso (TX) & $34.99 \mathrm{~N}, 101.90 \mathrm{~W}$ & 1,067 & 1997 to 2003 \\
University of Texas, Pan & $38.21 \mathrm{~N}, 104.57 \mathrm{~W}$ & 1,490 & 2007 to present \\
American (TX) &
\end{tabular}

Table B-6. BSRN Sites Within the United States

\begin{tabular}{lccc}
\hline Station Name & Latitude, Longitude & Elevation $(\mathbf{m})$ & Period of Record \\
\hline Barrow (AK) & $71.32 \mathrm{~N} \mathrm{156.60} \mathrm{W}$ & 8 & 1992 to present \\
Billings (OK) & $36.60 \mathrm{~N}, 97.52 \mathrm{~W}$ & 317 & 1995 to present \\
Bondville (IL) $^{*}$ & $40.06 \mathrm{~N}, 88.37 \mathrm{~W}$ & 213 & 1995 to present \\
Chesapeake Light (VA) $_{\text {Desert Rock (NV)* }}^{*}$ & $36.91 \mathrm{~N}, 75.71 \mathrm{~W}$ & 21 & 2000 to present \\
Fort Peck (MT)* & $36.63 \mathrm{~N}, 116.02 \mathrm{~W}$ & 1007 & 1998 to present \\
Goodwin Creek (MS)* $_{\text {Rock Springs (PA)* }}$ & $48.31 \mathrm{~N}, 105.10 \mathrm{~W}$ & 634 & 1995 to present \\
Table Mountain (CO) $^{*}$ & $34.25 \mathrm{~N}, 89.87 \mathrm{~W}$ & 98 & 1995 to present \\
\hline
\end{tabular}

${ }^{*}$ Coincident with SURFRAD station. 


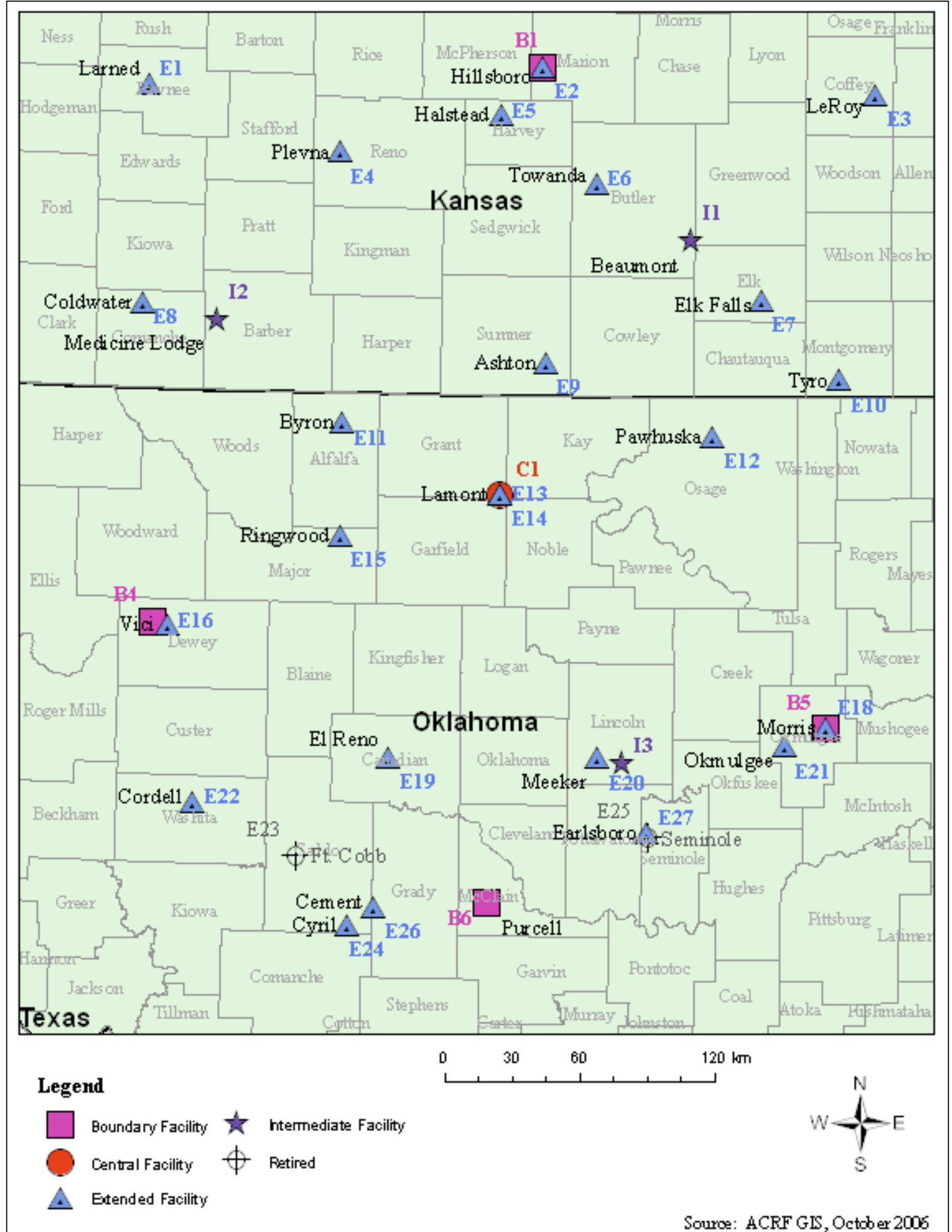

Figure B-1. DOE-ARM sites in the Southern Great Plains 


\section{Appendix C-Questionnaire Used to Solicit Input on Solar Resource Requirements}

\section{Input Sought in Support of Solar Resource Requirements for Grid Integration}

May 16, 2007

The National Renewable Energy Laboratory is seeking input on a solar resource assessment plan to guide future work in support of integrating solar generation technologies with the grid.

Potential new areas of research and development include the following.

- Forecasting of the solar resource. This includes forecasts in the immediate future, on the order of 1-15 minutes - or longer term, on the order of a day. Forecasts would predict variable generation capacity from solar technologies and aid in economic and power purchasing decisions.

- High temporal resolution characteristics of the solar resource. Answering such questions as: What is the variability of the resource; how long is a clear sky likely to persist; how stable is the resource on a minute-by-minute basis; can these characteristics be applied as solar climate zones.

- Quality of the resource for given technologies. Determining the magnitude of the direct beam relative to diffuse (to discriminate between solar concentrating and flat-plate technologies).

- The need for reduced uncertainty. Determining the desired data uncertainty for prospecting, siting, system monitoring, etc.

- Load matching. Addressing such questions as: How does the potential for generation relate to the demand on the system (e.g., solar loading on air conditioning); how do remote loads correlate with generation capacity.

- Need for increased spatial resolution data sets with meteorological data. Is $10-\mathrm{km}$ data resolution adequate for areas of high density loads?

- Need for instrumentation, data collection, and data visualization tools to provide site-specific measurements of the solar resources.

This information - as well as additional ideas received from respondents - will help direct areas of research to support the needs of utilities and industry to integrate solar energy applications with the power grid.

\section{Contacts}

Dave Renné (david_renne@nrel.gov ); Steve Wilcox (stephen_wilcox@nrel.gov). 


\section{REPORT DOCUMENTATION PAGE}

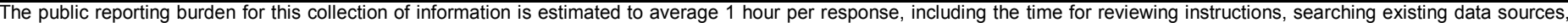

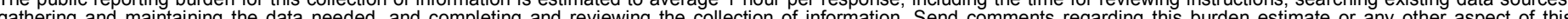

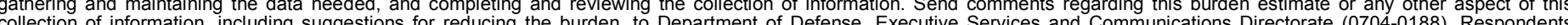

should be aware that notwithstanding any other provision of law, no person shall be subject to any penalty for faling the

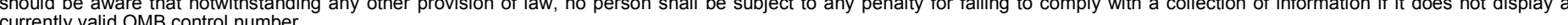

PLEASE DO NOT RETURN YOUR FORM TO THE ABOVE ORGANIZATION.

\begin{tabular}{l|l|l|l} 
1. REPORT DATE $(D D-M M-Y Y Y Y)$ & 2. REPORT TYPE & 3. DATES COVERED (FrOm - TO)
\end{tabular}

February 2008

Technical report

4. TITLE AND SUBTITLE

Solar Resource Assessment 5a. CONTRACT NUMBER

DE-AC36-99-G010337

5b. GRANT NUMBER

5c. PROGRAM ELEMENT NUMBER

5d. PROJECT NUMBER

NREL/TP-581-42301

5e. TASK NUMBER

PVB7.6401

5f. WORK UNIT NUMBER
7. PERFORMING ORGANIZATION NAME(S) AND ADDRESS(ES)

National Renewable Energy Laboratory

1617 Cole Blvd.

Golden, CO 80401-3393
8. PERFORMING ORGANIZATION REPORT NUMBER

NREL/TP-581-42301

9. SPONSORING/MONITORING AGENCY NAME(S) AND ADDRESS(ES)

10. SPONSOR/MONITOR'S ACRONYM(S) NREL

11. SPONSORING/MONITORING AGENCY REPORT NUMBER

12. DISTRIBUTION AVAILABILITY STATEMENT

National Technical Information Service

U.S. Department of Commerce

5285 Port Royal Road

Springfield, VA 22161

13. SUPPLEMENTARY NOTES

14. ABSTRACT (Maximum 200 Words)

This report covers the solar resource assessment aspects of the Renewable Systems Interconnection study. The status of solar resource assessment in the United States is described, and summaries of the availability of modeled data sets are provided.

15. SUBJECT TERMS

solar resource; assessment; renewable systems interconnection; National Renewable Energy Laboratory; NREL

\begin{tabular}{l}
\hline \multicolumn{3}{|l|}{ 16. SECURITY CLASSIFICATION OF: } \\
\hline \begin{tabular}{l|l|l|} 
a. REPORT & b. ABSTRACT & c. THIS PAGE \\
Unclassified & Unclassified & Unclassified \\
& & \\
\hline
\end{tabular} \\
\hline
\end{tabular}

\begin{tabular}{|c|c|}
\hline $\begin{array}{l}\text { 17. LIMITATION } \\
\text { OF ABSTRACT }\end{array}$ & $\begin{array}{l}\text { 18. NUMBER } \\
\text { OF PAGES }\end{array}$ \\
\hline UL & \\
\hline
\end{tabular}

19a. NAME OF RESPONSIBLE PERSON

19b. TELEPHONE NUMBER (Include area code) 